Cahiers $d u$ MONDE RUSSE

\section{Cahiers du monde russe}

Russie - Empire russe - Union soviétique et États indépendants

45/1-2 | 2004

Stratégies impériales

\title{
Crimean Tatars, Nogays, and Scottish missionaries
}

The story of katti Geray and other baptised descendants of the Crimean khans

\section{HAKAN KIRIMLI}

\section{OpenEdition}

\section{Journals}

Édition électronique

URL : https://journals.openedition.org/monderusse/8679

DOI : 10.4000/monderusse. 8679

ISSN : $1777-5388$

Éditeur

Éditions de l'EHESS

Édition imprimée

Date de publication : 1 janvier 2004

Pagination : 61-108

ISBN : 2-7132-2008-4

ISSN : $1252-6576$

Référence électronique

HAKAN KIRIMLI, «Crimean Tatars, Nogays, and Scottish missionaries », Cahiers du monde russe [En ligne], 45/1-2 | 2004, mis en ligne le 01 janvier 2007, consulté le 03 septembre 2022. URL : http:// journals.openedition.org/monderusse/8679; DOI : https://doi.org/10.4000/monderusse.8679 
chercher : repérer : avancer

Cet article est disponible en ligne à l'adresse :

http://www.cairn.info/article.php?ID REVUE=CMR\&ID NUMPUBLIE=CMR 451\&ID ARTICLE=CMR 4510061

Crimean Tatars, Nogays, and Scottish missionaries. The story of katti Geray and other baptised descendants of the Crimean khans

\title{
par HAKAN KIRIMLI
}

\section{Editions de l'EHESS | Cahiers du monde russe}

\author{
2004/1-2 - Vol 45 \\ ISSN 1252-6576 | ISBN 2713220084 | pages 61 à 108
}

Pour citer cet article :

-KIRIMLI H., Crimean Tatars, Nogays, and Scottish missionaries. The story of katti Geray and other baptised descendants of the Crimean khans, Cahiers du monde russe 2004/1-2, Vol 45, p. 61-108.

Distribution électronique Cairn pour les Editions de l'EHESS.

(C) Editions de l'EHESS. Tous droits réservés pour tous pays.

La reproduction ou représentation de cet article, notamment par photocopie, n'est autorisée que dans les limites des conditions générales d'utilisation du site ou, le cas échéant, des conditions générales de la licence souscrite par votre établissement. Toute autre reproduction ou représentation, en tout ou partie, sous quelque forme et de quelque manière que ce soit, est interdite sauf accord préalable et écrit de l'éditeur, en dehors des cas prévus par la législation en vigueur en France. Il est précisé que son stockage dans une base de données est également interdit. 


\title{
CRIMEAN TATARS, NOGAYS, AND SCOTTISH MISSIONARIES
}

\author{
The story of Katt1 Geray \\ and other baptised descendants of the Crimean khans ${ }^{1}$
}

The Crimean Tatars and their close ethnic kinsmen the Nogays played a significant role in the history of post-medieval Eastern Europe. Their active relations with several European powers and peoples in the course of centuries notwithstanding, one may think that the past of these Muslim Turkic peoples had little bearing on that of the faraway Scots. Still, there were some curious, albeit long forgotten, twists of history where the fortunes of the peoples of the Kipchak steps and that of the Caledonians intersected. One such case involved the activities of a group of Scottish missionaries in the North Caucasus and the Crimea during the first quarter of the nineteenth century. This unusual encounter not only refers to a daring enterprise on the part of a group of Scotsmen, but also highlights the interesting, and thus far rather blurry, changes in the social life of the Crimean Tatars and Nogays during the earlier decades of Russian rule over them. All these could be depicted against the background of the very exceptional fate and story of a member of the Geray dynasty who was directly affected by these developments, namely Kattı Geray or "Aleksandr Ivanovich Sultan-Kırım-Geray."

1. I would like to express my heartfelt thanks to Nurettin Demir, Wenzel Freiherr von Reiswitz, Roza Ayırçinskaya, Malcolm Vince Jones, Hans-Jürgen Kornrumpf, Mehmet Ali Doğan, and Ömer Turan who extended me very kind and invaluable assistance of various kinds during the process of the preparation of this article. 


\section{The Geray dynasty}

The Muslim and Turkic Geray dynasty, which was believed to have an unbroken genealogical link with Chinghiz Khan, ruled over the Crimean Khanate for more than three-and-a-half centuries. In turn, they descended from a branch of the ruling Chinghizid dynasty of the Golden Horde, the powerful empire which dominated vast areas stretching from eastern Europe to Central Asia during at least midthirteenth to late fourteenth centuries. The Gerays considered themselves the legitimate heirs of the Golden Horde and for them the state they ruled was nothing but the Golden Horde or Great Horde (Uluğ Orda) itself, a claim which they were keen to assert until the very end of the Crimean Khanate. The Geray line was directly linked to the fully Turkified and Islamized descendants of Juji, son of Chinghiz Khan.

The emergence of the name "Geray" as the epithet of a particular Chinghizid line goes back to the early fifteenth century. It was Hacı Geray Khan I who was to bear this name first and who made the Crimean peninsula the base of his and his descendants' realm. Following Hacı Geray Khan I, his male descendants would add this appellation to their personal names. ${ }^{2}$ The cognomen Geray (or Giray in the Ottoman usage), thus acquired a distinctive historical meaning as the name of the Turkic and Muslim ruling dynasty of the Crimean Khanate, independent from the etymological background of the term, which had, in all likelihood, been linked with the eponymic Turkic/Mongolian tribe Kerey, a historical community important in its own right. ${ }^{3}$ Until the end of the Crimean Khanate, and even thereafter, the Geray dynasty enjoyed great respect by outsiders as one of the oldest Asiatic and Muslim royal houses whose legitimacy has never been a matter of dispute. In the Ottoman Empire, which the Crimean Khanate from the last quarter of the fifteenth century on recognized as its sovereign, the Gerays, as a dynasty, were known to be second only to the Ottomans themselves.

The Russian annexation of the Crimea ended the rule of Gerays in the Crimea in 1783. Supported by the Ottomans, who could hardly reconcile themselves to the loss of the Crimea to the Russian Empire, the Gerays' sovereignty - at least nominally - continued over certain parts of the Kuban and Bucak regions which used to belong to the Crimean Khanate. The last Gerays to be declared khans by the Ottoman Empire as such were Şahbaz Geray Khan (1787-1789) and Baht Geray Khan (1789-1792). ${ }^{4}$ Following the Russian invasion of the Crimea, practically all Gerays belonging to the line of direct succession left (or were forced to leave) the

2. For the Geray dynasty, see Halil İnalcık, "Giray," The Encyclopedia of Islam (New Edition), vol. II (Leiden, 1983): 1112-1114; idem, "Giray," İslâm Ansiklopedisi, vol. IV (Istanbul, 1964): 783-789.

3. For the correlation between the terms and concepts "Geray" and "Kerey" (or "Kereit"), see Julius [Gyula] Németh, "Kereit, Kerey, Giray," Ural-Altaische Jahrbücher (Wiesbaden), vol. XXXVI (1965): 360-365. It should be noted that Hac1 Geray's adaptation of the term did not indicate, on his part, any genealogical link to the Kerey tribe.

4. Halim Geray Sultan, Gülbün-i Hânân yahud Kırım Tarihi (Istanbul, 1327 [1911]): 217-220. 
peninsula for the Ottoman Empire or for some of the former possessions of the Crimean Khanate on the Caucasus. At the turn of the nineteenth century, there was not such a single male descendant of the royal house of Gerays left in the Crimea. 5 Although some minor members (especially women) of the large Geray pedigree and individuals with varying degrees of relations to the Gerays continued to live in the peninsula, none of them were ever recognized as heirs to the former dynasty or ennobled by the Russian government owing to their ancestry. In other words, whatever stories the fate had in store for the individual descendants of the Gerays who still somewhat cherished their filiation after the demise of the Crimean Khanate, they would take place outside the Crimea.

\section{The Gerays in the North Caucasus}

Throughout its reign, the Geray dynasty had always maintained close relations with the Turkic and Adyge ("Circassian") peoples of the western section of the North Caucasus who constituted an important element in the khanate. The Gerays' ties with the nobility of the North Caucasian tribes were kept alive with the time-honored atalık tradition. ${ }^{6}$ According to this custom, every male member of the Geray dynasty, having reached a certain age of childhood, was ceremoniously sent to a Circassian noble family to be brought up in the virile arts of tough North Caucasian life. Apart from its important role in the upbringing of the young Geray sultans, this tradition provided the Gerays with the most trustworthy alliances among the North Caucasian nobility, whose prestige and influence in turn would be raised enormously if and when the sultan they brought up came to power. ${ }^{7}$

A living legacy of the Crimean rule in, and relations with, many a North Caucasian land and people is the widespread usage of the cognomen of the Crimean

5. Jean Reuilly, Travels in the Crimea and along the shores of the Black Sea (London, 1807): 59.

6. Vasilii Dmitrievich Smirnov, Krymskoe khanstvo pod verkhovenstvom otomanskoi porty do nachala XVIII veka (St. Petersburg, 1887): 348-349; Abdullah Zihni Soysal, "Kırım Hanzâdelerinin Kafkasya'da Talim ve Terbiyesi," Emel (İstanbul), no. 36 (1966): 17-19; Ali Barut, "Kırım Hanlığı ile Kuzey-Batı Kafkasya İlişkilerinde Atalık Müiessesesinin Yeri,” Emel (Ankara), no. 219 (1997): 21-27. For a broad analysis of this critical tradition among the Caucasian peoples of various ethno-linguistic origins, see K. I. Ashkhamatov, Atalychestvo: sushchnost' i vospitatel'naia funktsiia (Maikop, 2001); Mark Osipovich Kosven, Etnografiia $i$ istoriia Kavkaza. Issledovaniia i materialy (Moscow, 1961): 104-126.

7. Notably, the very emergence of the name Geray had to do with the atalık tradition, as it was believed to be derived from the name of the tribe which brought up Giyaseddin Khan, who as a gesture of respect to it, gave their name to his son Hac1. As a matter of fact, the name "Hac1" had to do with the Geray (or Kerey) tribe too, as Giyaseddin named his son as such because the infant was born at the day Giyaseddin's atalık Devletkeldi Sûfî of the Kerey tribe returned from the Hajj. Hacı Geray Khan, who was also brought up by Devletkeldi Sûfî, decided to make a permanent mark of respect to his atalık by decreeing the addition of the name "Geray" to the personal names of all his descendants to come. Halim Geray Sultan, op. cit.: 13-14. 
dynasty as personal names among them. ${ }^{8}$ Although many of the bearers of the name "Geray" (or its derivations) were or are actually related to the Geray dynasty, many others who had some form of Geray in their names or surnames hardly had anything to do with actual Chinghizid origins.

During the times of the Crimean Khanate, the territories and peoples of the North Caucasus under its jurisdiction were ruled by a Geray who bore the title of serasker. ${ }^{9} \mathrm{He}$ was one of the highest dignitaries of the Crimean state and under his command was the eastern branch of the Nogay cavalry which constituted a very important part of the army. The Nogays, a quintessential Kipchak Turkic and Muslim people, were distinguished from the "proper" Crimean Tatars with their semi-nomadic way of life, ancient tribal social structure and more pronouncedly Asiatic culture and physiognomy. Traditionally, they lived in the vast steppes to the north of the Crimean peninsula. Following the demise of the Crimean Khanate, a large group of the Nogays were forced to move beyond the Kuban river together with some members of the Geray dynasty. These Gerays thus remained among the Nogays even after the latter had to accept the Russian rule. For the most part having retained the title "sultan" (of course with a much reduced authority and political meaning in the absence of the khanate), they would constitute the highest social category among the Nogays. A number of them would later be offered military and administrative ranks as they entered the Russian service. The tsarist government recognized their royal descent and included them within the "hereditary nobility" (potomstvennoe dvorianstvo). ${ }^{10}$ It was possible to encounter other Gerays who had become local nobles (or notables) among various tribes in the region. Already during khanate times there were many Geray princes (Sultans) who had settled among the Adyge tribes in the Kuban region, without assuming any official role in the administration. ${ }^{11}$ Among them, some were thoroughly "Circassianized" over time. ${ }^{12}$

8. The name "Geray" and its various somewhat modified forms due to the local pronunciations, such as "Girey," "Gerey," "Geri," etc., has been a commonplace personal name among many North Caucasian peoples to this very day. It is added after another name (e.g., Arslan Geray, Kılıç Girey, Mehmet Gerey, etc.), as was the case among the Crimean royal dynasty, rather than being used as a first name itself. It is possible to encounter it not only among the Kipchak Turkic peoples of the North Caucasus (i.e., Karachay-Balkars, Kumuks, and Nogays), who are close ethnic kinsmen of the Crimean Tatars, but also or even more so among other regional groups especially the Adyge communities, as well as the Chechen-Ingush and the peoples of Dagestan. On the other hand, one should distinguish the usage of Geray (in its various forms or its derivatives) in the Volga-Ural region and Central Asia, which might not necessarily have to do with the Crimean Gerays but might be connected to the intrinsic presence of the name Kerey (and related forms) there as an ethnonym.

9. William Eton, A survey of the Turkish Empire (London, 1799): 326.

10. Bi-Arslan Balbekoviç Koçekayev, Sotsial'no ekonomicheskoe i politicheskoe razvitie nogaiskogo obshchestva v XIX-nachale XX veka (Alma-Ata, 1973): 138-139.

11. Tunmann [Johann Thunmann], Krymskoe khanstvo (Akmescit/Simferopol, 1991): 64.

12. A. Z. Soysal, art. cit.: 19. Han Geray or Kırım Girey Mehmet-Gireyev Han-Girey (1808-1842), the early intellectual figure who contributed a great deal in the study and recording of the North Caucasian mountain culture in general, and the Adyge one in particular, descended from a such "Circassianized" Geray family. Khan-Girey, Cherkesskie predaniia. Izbrannye proizvedeniia (Nalchik, 1989): 8. So were those other Crimean Tatar-cum-Adyge intellectuals who were brought up, and wrote, in the Russian milieu, Sultan Gazi Geray and Sultan Kırım Geray. 
These resident Gerays in the North Caucasus also stayed there after the collapse of the Crimean Khanate. As a matter of fact, the khanukos (literally, the "khan's sons"), one of the highest noble elements in Adyge societies, were scions of the Gerays who, due to a variety of reasons, had ended up settling among the Adyges. ${ }^{13}$ The Russian government which had practically wiped them from their native Crimea was willing to coopt Gerays in the North Caucasus. This eagerness of course had much to do with the idea of making use of their prestige among the Turkic and other tribes of the region, in the middle of the very costly and complex process of the Russian conquest of the North Caucasus.

However, most of these Gerays in the North Caucasus had few followers and little authority other than the once-glorious memories of their title. An outside observer, with an unconcealed disdain, would note that the only symptoms of royalty to be discovered among these members of the Geray family then were "empty titles and proud hearts, amidst dissatisfaction and poverty." 14 During the first decade of the nineteenth century, among Gerays in the Russian controlled parts of the North Caucasus were Murat Geray Has Geray, who resided on the Laba above the Navruzaul (with about forty families under his authority), his brother Devlet Geray Has Geray, who lived among the Abadzehs in the Black Mountains on the river Kujeeps (with about forty families as his dependants), the children of Sultan Arslan Geray and the brothers of Sultan Mengli Geray who resided among the Nogays on the Great Zelenchuk (İncik) river. ${ }^{15}$

The latter branch, which was living in quite indigent circumstances, was related to Gazi Geray Sultan who used to be the former Serasker of Kuban and who, upon his dismissal from this post, had offered his services to Russians in 1778. ${ }^{16}$ This was very much appreciated by the Russians, particularly pending their final invasion of the Crimea. Gazi Geray Sultan's nephew, Mengli Geray, was also in the service of the Tsar and had received the rank of major general. ${ }^{17} \mathrm{He}$ had been given the title "Nogay Bailiff" (nogaiskii pristav), that is, the head of the Nogays, by Tsar

13. S. K. Bushuev, M. G. Autlev, E. L. Kozhesau, Ocherki istorii Adygei (Maikop, 1957): 187. For the names of some Geray princes residing among the Circassian tribes during the last decade of the eighteenth century, see Jean-Louis Mattei, "Kırım ve Kafkasya'da Osmanlı Nüfuzunun Gerilemesi ve Ruslara Karşı Kafkas Kabilelerinin Direniş Girişimleri (1792) III," Toplumsal Tarih (Istanbul), no. 9 (September 1994): 22-25.

14. From the Report of Robert Pinkerton, "Scottish Missionary Society, Account of the Tartars and Circassians," The Missionary Register(London) (May 1820) : 212.

15. Ibid.; Heinrich Julius von Klaproth, Travels in the Caucasus and Georgia, performed in the years 1807 and 1808, by command of the Russian Government (London, 1814): 263-264.

16. N. F. Dubrovin, ed., Prisoedinenie Kryma k Rossii. Reskripty, piśma, relatsii i doneseniia, vol. II (St. Petersburg, 1889): 370-374.

17. H. J. von Klaproth, op. cit.: 209. Prior to his defection, Gazi Geray Sultan, in defiance of the ruling khan and his brother Şahin Geray Khan, had requested from the Russians to be named the independent Serasker over the Nogays. However, Russians had refused, in order not to further weaken the authority of Şahin Geray Khan who had been their own candidate to the Crimean throne. N. F. Dubrovin, ed., Prisoedinenie Kryma $k$ Rossii. Reskripty, pis'ma, relatsii $i$ doneseniia, vol. I (St. Petersburg, 1885): 370-371; Alan Washburn Fisher, The Russian annexation of the Crimea 1772-1783 (Cambridge, 1970): 120-121. 
Aleksandr I in $1803 .{ }^{18}$ Sultan Mengli Geray, ${ }^{19}$ indeed, enjoyed great respect on the part of both the Nogays and the Abadzehs. ${ }^{20}$ Sultan Selâmet Geray, the brother of Sultan Mengli Geray, ruled over the Nogay tribes of Mangits, Kıpçaks, and Kasbulats which were dwelling along the Great Zelenchuk and Urup (Uarp). ${ }^{21}$ The two other brothers of Sultan Mengli Geray, namely Sultan Azamat Geray and Sultan Maksud Geray were also commanding a group of local Nogays and reached the rank of major. ${ }^{22}$ Sultan Azamat Geray was the chief of the Toktamış tribe of the Nogays..$^{23}$

A community of Nogays who had settled in the region of Beştav or Piatigorsk at the turn of the nineteenth century were under the authority of Sultan Mengli Geray. Apparently the Nogays had spread to a number of villages (auls) in the Beştav (Piatigorsk) district. In 1822, when he was freed from office, in return for his services to the Russian state, the Tsar bestowed upon Sultan Mengli Geray 5,000 desiatins of land on the river Kuma "for eternal and hereditary use" and an annual pension of 4,800 roubles. ${ }^{24}$ This estate of Sultan Mengli Geray consisted of a vast steppe area where the city of Mineralnye Vody and its surroundings are found

18. "Vysochaishee povelenie na imia kn. Tsitsianova, ot 13-go fevralia 1803 goda. S.Peterburg," Akty Sobrannye Kavkazkoiu Arkheograficheskoiu Kommissieiu, vol. II (Tiflis, 1868): 21. Sultan Mengli Geray had been (perhaps for educational purposes) in St. Petersburg in his youth and was quite familiar with international politics, as well as with regional affairs. Curiously, as noted by William Glen, a Scottish missionary from Astrakhan who visited him in 1820, Sultan Mengli Geray could scarcely read his own language. William Glen, Journal of a tour from Astrachan to Karass (Edinburgh, 1823): 143.

19. The title "Sultan" within the context of the Crimean Khanate, parallel to the most Turkic/ Muslim state practices, when applied to princely personalities inferior to the Sovereign or the Khan always followed the personal name (e.g., Devlet Geray Sultan, Kırım Geray Sultan, etc.). The usage of the title preceding the personal name was the prerogative of the Sovereign himself. This was the case with the Ottomans whom the Crimeans also abode by (The Ottomans, however, used the title Sultan other than the Sovereign himself only for the female members of His Majesty's immediate family, and then, only at the end of the name. For some period, this title was used for the sons of the Sovereign too, preceding the latters' names, though this practice was not continued long. Mehmet Zeki Pakalın, Osmanlı Tarih Deyimleri ve Terimleri Sözlüğ̈̈, vol. III (Istanbul, 1971): 275.) Under Russian rule, apparently those few Gerays who entered into the Russian service and whose royal-cum-noble status was recognized by the Russian government carried the title "Sultan" (more or less in the sense of "Prince") preceding their names, true to the Russian (or rather the general European) tradition of using nobility titles (e.g., Sultan Mengli Geray, Sultan Adil Geray, etc.). This, somewhat ironically, symbolized their transfer from the royal dynasty of the Muslim and Oriental Crimean Khanate to the nobility of the Christian and European Russian Empire. Needless to say, their new status entitled them to a shallow authority in comparison to their (or their forefathers) former power only.

20. "Otnoshenie gen. Rtishcheva k kn. Gorchakovu 1-mu, ot 5-go ianvaria 1814 goda, no. 5," Akty Sobrannye Kavkazskoiu Arkheograficheskoiu Kommissieiu, vol. V (1873): 855 and "Raport gen.-m. Del'potso gen. Rtishchevu, ot 23-go aprelia 1814 goda, no. 238.- Georgievsk," ibid.: 872 .

21. "Raport gen.-m. sultana Mengli Gireia gen. Tormasovu, ot 1-go iiulia 1811 goda, no. 236.Georgievsk," Akty Sobrannye Kavkazskoiu Arkheograficheskoiu Kommissieiu, vol. IV (1870): 838 .

22. "Raport polk. Akhverdova gen. Tormasovu, ot 30-go Aprelia 1809 goda, no. 945.- Lager pri r. Cherek," Akty Sobrannye Kavkazskoiu Arkheograficheskoiu Kommissieiu, vol. IV (1870): 910.

23. Koçekayev, op. cit.: 118-119.

24. Ibid.: 121 and 139. 
today. ${ }^{25}$ The title "Nogay Gendarmerie Chief" was later given to Sultan Adil Geray. ${ }^{26}$ According to an official Russian report of late 1802, around Beştav (Piatigorsk) there were 5,342 "tilt carts" (kibitki), i.e., households, of Nogays composed of the Kasbulat, Kıpçak, Yedisan, Cemboyluk, and Navruz tribes. ${ }^{27}$

\section{The emergence of the Scottish missionaries in the North Caucasus}

Shortly after the turn of the nineteenth century, a small group of unanticipated sojourners, in the form of Scottish Presbyterian missionaries, came to this area in the midst of the Nogays. They were led by Reverend Henry Brunton and Alexander Paterson. Tsar Alexander I had considered the appeal of the Edinburgh Missionary Society to "turn various barbarian peoples to an enlightened position" positively and had offered them land to settle in the Beştav region in 1802.28 The Scottish missionaries, who initially consisted of fifteen persons including the family members, ${ }^{29}$ thus established themselves in the village of Karas within the Nogay lands, under the authority of Sultan Mengli Geray and other local Gerays. In other words, the village was actually a part of the Gerays' estate. ${ }^{30}$ Karas was located not far from the Russian military base of Georgievsk and it was adjacent to the territory of the Adyge Kabardians. ${ }^{31}$ A novel method thought up by the missionaries to

25. Viktor Borisovich Gritsenko, Istoriia zemli Mineralovodskoi (Mineralnye Vody, 1998): 33. After the death of Sultan Mengli Geray in 1830, the administration of his estate, with several households and a mosque, passed to his sons, Canıbek Geray and Toktamış Geray. A part of their land was allotted to the construction of a railway and its station (with the name Mineralnye Vody, i.e., Mineral Waters) during the first part of the 1870s. It was then that a large number of Russian settlers also came to the area of the farm of the Gerays which officially became the village of Sultanovskii in 1878. It was renamed Illarionovskii in 1906. This village, together with the railway station, would develop into a famed town of spas, which would later officially take the name of Mineralnye Vody. Ibid.: 34-42.

26. Koçekayev, op. cit.: 139.

27. "Vypiska iz dela o kochuiushchikh v Astrakhanskoi gubernii narodakh," Akty Sobrannye Kavkazkoiu Arkheograficheskoiu Kommissieiu, vol. II (1868): 924.

28. "Reskript kn. Tsitsianovu, ot 28-go noiabria 1802 goda," Akty Sobrannye Kavkazkoiu Arkheograficheskoiu Kommissieiu, vol. II (1868): 926-927; "Foreign intelligence. GeorgiaKarass," The Missionary Register for the Year 1814, vol. II (London, 1814): 358-359. For a general survey of the activities of the Scottish missionaries in the Caucasus and the Crimea during early nineteenth century, see J. Baxter, "Scots in the Caucasus. A curious missionary enterprise," The Scots Magazine (Edinburgh), New Series, vol. XVI, no. 1 (October 1931): 19; Ömer Turan, "XIX. Yüzyılda Kırım, Kafkasya ve Civarında Misyonerlik Faaliyetleri," Belleten (Ankara), vol. LXIV, no. 241 (2000): 921-947.

29. "Religious intelligence," The Religious Monitor, vol. I (Edinburgh, 1803): 155.

30. V. Ia. Simanskaia, "Shotlandka - Selenie Karras (Lermontovskie mesta Piatigor'ia)," Mikhail Iur'evich Lermontov. Sbornik statei i materialov (Stavropol, 1960): 200.

31. For a colorful and quite detailed narrative of the Scottish missionary colony in Karas, see Malcolm V. Jones, "The sad and curious story of Karass 1802-35," Oxford Slavonic Papers, vol. VIII (1975): 53-81. Also, see Gordon Stewart, "Schotlanskaya-Kolonia," The Stewarts, vol. 19, no. 2 (1993): 102-104. The name of the village was spelled in English texts usually as "Karass" or "Carass." Among the two forms "Karas" and "Karras" which conform to the pronounciation and spelling of the official name of the village then and now, throughout this article, 
introduce Christianity to the local Muslims was to ransom slave youths from the mountaineers and to educate them in the colony as Christians. To this effect, special permission was obtained from the Russian authorities for redeeming captives (or slaves) from "Circassians and Transkubanians," provided that such purchased people would not be older than sixteen years of age and would be allowed to leave the missionaries at twenty-three. The permission excluded the purchase of Russian and Georgian prisoners from the mountain tribes for this purpose. ${ }^{32}$

Reverend Brunton, an experienced, elderly missionary, was the head of the Scottish mission. He had worked in the neighborhood of Sierra Leone from 1797 to 1801. Notwithstanding the extreme hardships he had endured during his missionary activity in Africa, he had not abstained from studying the languages of the local African tribes. He had published scholarly works about these languages upon his return to Scotland. Brunton had prepared the first grammar of the Susu language which was spoken along the West African coast. ${ }^{33} \mathrm{He}$ also had a good command of Arabic. In spite of his outstanding skills in learning foreign tongues, at the time of his arrival in the Caucasus Brunton spoke neither any of the local languages nor Russian. This was also the case with the other missionaries. They were not well-versed in the history, cultures, and traditions of the region and the peoples therein either. This being a serious handicap, however, Brunton's knowledge of Arabic was deemed an important asset approaching the Muslims. Moreover, with great zeal, they began to learn local Turkic and Adyge languages. ${ }^{34}$ Indeed, they displayed a remarkable success, especially in the former, to the point of attaining the self-assurance to publish pamphlets and even the New Testament in Turkic within a short span of time.

I preferred the form "Karas." According to the Scottish missionaries, the toponymic originated from the corrupted form of the Turkic phrase Kara Sultan (Black Sultan), after a Sultan (in all probability, a Geray) who had first settled in the land. "Edinburgh Missionary Society," The Religious Monitor, vol. VII (1809): 566. Another missionary source also attributes the origin of the toponymic Karas to a Tatar Sultan who, with several of his sons, was buried a few kilometers north of the village. Ebenezer Henderson, Biblical researches and travels in Russia (London, 1826): 446. This version is also reiterated in, William Canton, A history of the British and Foreign Bible Society, vol. I (London, 1904): 179. There is also the suggestion that the toponymic might have originated from the Turkic phrase Kara As, i.e., "Black As" ("As" is an ethnonym pertaining to the ancient Alans, which is also the name of a Kipchak/Nogay tribe). Vladimir Fomenko, "Arkheologicheskie pamiatniki Piatigor'ia i rannaia istoriia nogaitsev predkavkaz'ia,” Polovetskaia Luna (Cherkessk), no. 1 (8) (1994): 115-116.

32. "Vypiska iz Vysochaishe konfirmovannago doklada ministra vnutrennikh del, ot 25-go noiabria 1802 goda, v S.-Peterburg, otnositel'no predlozhenii Shotlandtsev Brontona i Patersona k poseleniiu kolonii," Akty Sobrannye Kavkazkoiu Arkheograficheskoiu Kommissieiu, vol. II (1868): 926; "Abstract of the report of the Committee of the Mission Society to Africa and the East, delivered at the Annual Meeting, on the 31st May, 1803," The Religious Monitor, vol. I (1803): 277; M. V. Jones, art. cit.: 57.

33. J. H. Baxter, art. cit.: 3; William Brown, History of the propagation of Christianity among the heathen since the Reformation, vol. II (Edinburgh, 1854): 415-420; P. E. H. Hair, "A Scottish missionary in the Caucasus: Henry Brunton," Bulletin of Scottish Institute of Missionary Studies, vol. 13, n 1-4 (1973) : 28. "Jellorum Harrison," a young Susu from Guinea, also accompanied Brunton to the Caucasus in 1802. P. E. H. Hair, "A West African in Tartary," West African Review (London) (May 1962): 45-47.

34. M. V. Jones, art. cit.: 79. 
Notwithstanding the ardor and prospects of Brunton and his fellow missionaries, who long cherished the dream of "the conversion of the Tartars and other nations, situated between Europe and India," 35 they failed to make any serious progress in making converts among the local population, with the exception of a very few individuals whose approach to them was equivocal at best. Anyway, they were compelled to live a life quite isolated from the local tribes to whom they had little means to reach out.

In fact, the problems of the missionaries in Karas were common to all their fellow missionaries in other Muslim regions under the rule of the Russian Empire. Everywhere they worked, the Scottish missionaries approached their task as if they were introducing their message into a spiritual vacuum, tending to ignore the depth of the current creed. It was quite apparent from their reports that once they were able to talk to a Muslim at some length, or especially to present him with any of the tracts they published, they were pretty confident that he would already be on the way becoming a Christian. No doubt, Islam proved to be much more deep-seated and stronger among the North Caucasian mountaineers and peoples of the steppes than the Scottish missionaries thought, especially as it was the most important means of defending one's identity vis-à-vis the Russian rulers. Islam commandeered not only individual consciences but dominated every aspect of social and cultural life. Religion proved such an indispensable pillar of societal identity that even the nomadic and Buddhist Kalmucks, who were considered even readier to be Christianized, stiffly resisted.

The troubles of the mission in Karas were by no means confined to their lack of success in evangelizing among the natives. The Scottish mission had settled in the Northern Caucasus when political and social circumstances were extremely precarious. The upsurge of the war between the Muslim mountaineers and the Russians, the outbreak of the Ottoman-Russian war, not to mention the volatile political situation during the first decade of the nineteenth century in Europe, which was certainly reflected in the relations between Russia and Britain, deeply affected the border village of Karas. To make matters worse, plague spread in the region directly threatening Karas in 1804. Due to these circumstances, the peoples in the region were frequently on the move. At one point, the missionaries had to leave the village temporarily for the fortified Russian town of Georgievsk in the face of the plague and disorders. Some missionaries, among whom was the wife of Paterson who was also Brunton's sister, lost their lives as a result of the epidemic. Throughout all these hard times, the Scots enjoyed the protection and support of Sultan İslâm Geray, the head of the Nogays in Karas. ${ }^{36}$ Although the mission returned to Karas and assumed its work after an improvement in the circumstances, this would not be the last turmoil they would experience; they were

35. "Abstract of the report of the Committee of the Mission Society to Africa and the East...," art. cit. : 276.

36. "Religious intelligence. Edinburgh Missionary Society," The Religious Monitor, vol. II (1804): 468-469. 
to move out of Karas and come back in $1809 .{ }^{37}$ After the last move, soldiers and Cossacks, whose number would at one point reach as many as 180 , were assigned to protect them. ${ }^{38}$

Yet, all these hardships could not break the zeal of the mission. They kept purchasing slaves from the mountain tribes. Many of the missionaries also had remarkable success in learning the local Turkic. This encouraged them to make translations of Christian scriptures and publish them in Turkish. By late 1805 they had even set up a printing press in the village and commenced their publishing work. ${ }^{39}$ Within a few years they not only printed two catechisms and at least two propaganda pamphlets, but also gradually translated the Gospels into Turkish and published them piecemeal. ${ }^{40}$ The publication of the New Testament in Turkish was completed in $1813 .{ }^{41}$ In this work, the Scottish missionaries were furnished the types, ink, and paper by the British and Foreign Bible Society. ${ }^{42}$ Most of the translation was done by Brunton.

Still, the little more than a handful of converts the Scottish mission was able to obtain amounted to the ransomed young slaves whom they brought up as Christians ${ }^{43}$ In spite of all their efforts, they failed to attract local Muslims. Amidst this unpromising state of affairs, the interest displayed by a young Tatar boy, a member of the local Geray family, generated a great deal of excitement among the missionaries. From the very outset of the missionaries' acquaintance with this Tatar teenager, information about him and his developing friendship with the missionaries began to appear regularly in the monthly journal of the Edinburgh Missionary Society, namely The Religious Monitor, and would be cited in parallel

37. M. V. Jones, art. cit.: 60.

38. Ibid.: 61

39. Extract of a letter from Mr. Pinkerton, to the Secretary of the Edinburgh Missionary Society," The Religious Monitor, vol. IV (1806): 118. For financing the typographical works and its paper supply the Edinburgh Missionary Society asked and received the sponsorship of the British and Foreign Bible Society. "Report of the Directors of the Edinburgh Missionary Society, to the annual meeting of the members of that Society, held at Edinburgh, the 19th day of April, 1808," in George Lawson, A sermon, preached before the Edinburgh Missionary Society (Edinburgh, 1808): 57-58.

40. According to Klaproth and Adelung, their publications included Íncil Dininin Strr1 [?] [The essence of the religion of the New Testament], Bir Dostun Kelâmı Müslümana [A friend's word to the Muslim] (Karas, 1806), Sual Kitabı [The book of questions / Catechism] (Karas, 1807), Ísa'nın Incili, Matta'nın Yazısı [The Testament of Jesus, Matthew's Gospel] (Karas, 1807). The Turkish translations of the Gospels of Luke, John, and Mark were also published, probably, in 1807. Johann Christoph Adelung, Mithridates oder Allgemeine sprachkunde, mit dem Vater unser als sprachprobe in bey nahe fünf hundert sprachen und mundarten, vol. IV (Berlin, 1817): 144; H. J. von Klaproth, op. cit.: 273 . These titles as rendered, if not recorded incorrectly, by Adelung and Klaproth, give the impression that they were in rather pidgin Turkish.

41. Incil-i Mukaddes yani Lisân-1 Türkîye Tercüme Olunan Bizim Rabbimiz İsa Mesih'in Yeni Ahd ve Vasiyyeti (Karas, 1813).

42. "British and Foreign Bible Society," The Edinburgh Christian Instructor (Edinburgh), vol. IX (1814): 121; W. Canton, op. cit.: 180.

43. A practice of the Scottish missionaries was to rename these ransomed, and later christened, youths, with the names of their sponsors in Scotland. G. Stewart, art. cit: 103. 
missionary journals. Obviously, the missionaries attributed a great deal of importance to, and were delighted with the hope of, the embracing of Christianity by this member of the Geray family.

\section{Kattı Geray}

The name of the young Geray whom the Scottish missionaries focused their attention was (in all likelihood) Kattı Geray. ${ }^{44}$ Though he undoubtedly belonged to the Geray dynasty, the royal line he directly descended from and even the name of his father are uncertain. What is known was that his father had died during infancy and he had been brought up by his uncle İslâm Geray. He was also a relative of Sultan Mengli Geray, the head of the Nogays in the Beştav region. ${ }^{45}$ An official Russian document, prepared upon his appeal for the acknowledgement of his nobility status, stated that he descended from the "former Crimean Tatar ruler [obladatel'] Kiz Girey Khan."46 There was, of course, no Crimean Khan with this corrupted name, though there indeed were three Gazi Geray Khans, the last of whom died in 1708.47 Actually, in an application to the Senate about his noble status, Kattı Geray described himself as an offspring of Kazı (i.e., Gazi) Geray. ${ }^{48}$ Apart from the three earlier khans, there were several Geray princes with the name Gazi. During the last decade of the khanate there existed two Crimean princes with the name Gazi Geray Sultan, both of whom played certain roles in the events of that

44. His actual name, in fact, is quite controversial. In the letters of the missionaries it was spelled as "Katagerry," "Kategeray," "Categary," "Kattegary," etc. The documents in the Russian language, which renders phonetical features better than English, spelled his name as "Katy." As neither version conforms to the common names used by the Gerays or even to the conventional Muslim names, it is not easy to pinpoint the Turkic (or perhaps Arabic or Persian) word which these foreign and certainly disfigured forms corresponded to. In the absence of the original (i.e., Turkic written in Arabic script) spelling of the young Geray's name, the Russian spelling seems to be nearest to it. Anyway, there is indeed the word katı (or qattı in Kipchak Turkic) in Turkic meaning "hard" or "tough." It should also be stated that although this is a very old and well established word in most Turkic languages and dialects, its was not common as a personal name and unprecedented among the Gerays. There was at least one Crimean Khan, namely Selim Geray Khan II (1743-1748), however, whose nickname was "Tough" (Qattı). Halim Geray Sultan, op. cit.: 173. Thus, throughout this article we shall refer to him (in accordance with the modern Turkish spelling, of course, like all other Turkic names and words) as "Kattı Geray," believing that this must have been the actual case.

45. His relation to Sultan Mengli Geray was mentioned in a letter of the missionaries where the latter was referred to as "a Major General in the Russian army" (The only Russian Major General of Geray origin in the region was Sultan Mengli Geray). "Edinburgh Missionary Society. Intelligence from Karass," The Religious Monitor, vol. VI (1808): 96.

46. Tsentral'nyi Gosudarstvennyi Arkhiv Avtonomnoi Respubliki Krym [Central State Archives of the Crimean Autonomous Republic; hereafter to be cited as TsGAARK] (Akmescit/Simferopol), f. 49, op. 1, d. 5640,1. 2.

47. Halim Geray Sultan, op. cit.: 140.

48. V. A. Alekseev, "Shagin-girei, poslednii khan krymskii," Nasha Starina (St. Petersburg), no. 5 (May 1914): 453. It is interesting to note that the Senate turned down Katt1 Geray's appeal then (in 1839). 
turbulent period. ${ }^{49}$ One of them was the previously mentioned Gazi Geray, the former Serasker of Kuban and the brother of the former khan of the Crimea, Sahin Geray Khan. Since Gerays around the Beştav (Piatigorsk) region (including Katt1 Geray) were known to be relatives of this Gazi Geray, it is very likely that Katt1 Geray was his descendant (and possibly his son). It should be remembered that Serasker Gazi Geray never became a khan.

According to a narrative current among his grandchildren, Kattı Geray's father was a Circassian (sic) sultan who, having been defeated by the Russians, had submitted to the latter. His brother, who had opposed alien rule categorically, stabbed him to death. Thus, allegedly, at the age of four, Kattı Geray was left an orphan..$^{50}$ Another family story was similar to this account, and it alleged that the infant Kattı had been saved by faithful servants who took him away and submitted him to the Scottish missionaries in the Caucasus. ${ }^{51}$ Both stories seem to be of a quite dubious nature, but they might contain at least a grain of truth in them. Although it was clear that he was not "submitted" to the Scottish missionaries, it is quite possible that his father might have died (or have been killed, for that matter) while he was four years old.

From a document prepared by himself, it may be ascertained that Kattı Geray was born in 1789.52 This alone suffices to refute the fantastic stories which emerged later about his being the son of Şahin Geray Khan, the last Crimean khan. ${ }^{53}$ Such allegations could not possibly have any relation to reality, if for no other reason than that this excessively controversial Crimean khan had been executed in Turkey in 1787 , i. e. two years before Kattı was born. According to another version, Kattı was the son of a Selim Geray Khan who had allegedly lost his life during a futile attempt to recover the khanate. A servant, the story goes, saved the life of the infant Katt1 and took him to his relatives in the Caucasus. ${ }^{54}$ Selim Geray Khan III (the only

49. N. F. Dubrovin, ed., Prisoedinenie Kryma k Rossii, op. cit., I: 452.

50. Ida Freiin von Gersdorff, "Abschrift von Aufzeichnungen von Ida Freiin v. Gersdorff nach den Erzählungen ihrer Mutter, Charlotte Freifrau v. Gersdorff, geb. Sultana Krim-Ghirey," manuscript, copy in the possession of the author (Courtesy of Wenzel Freiherr von Reiswitz): 6; Anna Sokol, "Übersetzung der Aufzeichnungen in englischer Sprache von Anna Sokol geb. Sultana Krim-Ghirey" manuscript, copy in the possession of the author (Courtesy of Wenzel Freiherr von Reiswitz; the whereabouts, or the existence, of the English original of these personal memoirs of Anna Sokol is not known to von Reiswitz): 9-10. Also, Wenzel Freiherr von Reiswitz, “Katté Giray,” Emel(Istanbul), no. 116 (1979) [Hereafter cited as Reiswitz I]: 23.

51. Reiswitz I: 23-24.

52. At the time of the writing of the document (1816) he was 27 years old. TsGAARK, f. 49, op. 1, d. $5640,1.2$.

53. Reiswitz I: 24-26. Reiswitz, whose wife was a granddaughter of Kattı Geray's daughter, however, rectified this misinformation later in the face of convincing evidence. Wenzel von Reiswitz, "Ein Nachfahre Tschingis-Chans wird zum Stammvater einer deutschen Familie," Deutsches Adelblatt (Brauchitsdorff, Schlesien), vol. XXIV, no. 6 (15 June 1985) [Hereafter cited as Reiswitz II]: 124, and "Katte Girei. Sein Weg vom Islam zum christlichen Glauben," manuscript, copy in the possession of the author (Courtesy of Wenzel Freiherr von Reiswitz) [Hereafter cited as Reiswitz III]: 2.

54. J. B. P., “An old Edinburgh romance,” The Scotsman(Edinburgh), 22 August 1914. 
Selim Geray Khan who reigned during the last decade of the khanate) did not lose his life during any attempt but died peacefully in his mansion in Ottoman Rumelia in 1785.55 Based merely on hearsay from a century ago from a distant foreign land, this version of Katt1's origins is hardly reliable, though it may contain some bits of relevance to the actual facts. Kattı Geray's subsequent use of the surname SultanKırım-Geray (Sultan-Krym-Girey) may suggest that he was a direct descendent of a Kırım Geray. Indeed, not only one of the last (and much famed) Crimean khans was Kırım Geray Khan, but there were several other members of the Geray dynasty with that name. There is the possibility that Kattı was a grandson of Kırım Geray Khan. His adoption of this surname, however, might simply have to do with an intention to signify his being a descendent of the Crimean khans. ${ }^{56}$ At this point, his symbolic patronymic in his Russified name, that is, Aleksandr Ivanovich Sultan-KrymGirey, is of no help in determining the actual name of his father, whose name was certainly not Ivan.

\section{Katt1 Geray embraces Christianity}

Katt1 established contacts with the Scottish missionaries in his village sometime no later than early 1803. By then, at least Brunton and Paterson had already developed their level of Tatar (i. e., Crimean or Nogay Kipchak Turkic) enough to be able to converse with him. He was impressed by their knowledge and amicable approaches, and made up his mind to stay with them in order to learn Arabic. During this period, under the strong influence of the missionaries, he began to question his faith. Not surprisingly, his intimacy with the Christian missionaries was too much to stomach for many among his fellow countrymen who had already begun to call him an infidel.$^{57}$ Katt1 also received a number of threats, upon which he complained to the Russian Commander at the nearby fortress of Konstantinogorsk about his relations. The Russian General reprimanded the latter and made it clear that Kattı was under his protection. Attaching great importance to winning Kattı over, the missionaries endeavored to employ a cautious tactic by not directly asking him to profess Christianity but rather by trying "to fix guilt on his conscience." Initially, Kattı vacillated. At times he would be reluctant to renounce Islam, at others he would declare his intention to sever all his ties with it. ${ }^{58}$ At one point he yielded to the pressures on the part of his family and left the Scottish mission, only to express his desire to return soon under the protection of the

55. Halim Geray Sultan, op. cit.: 184.

56. The Turkic word Kırım (or Qırım) stands for both the Crimea (the land) and the personal name of a Crimean khan, i.e., Kırım Geray Khan.

57. "Extract of a letter from Messrs. Brunton and Paterson, to the Secretary of the Edinburgh Missionary Society," The Religious Monitor, vol. I (1803): 278-279. This letter happened to be the first mentioning of him in The Religious Monitor.

58. "Extract of a letter from the missionaries at Karass in Russian Tartary, dated 1st Oct. 1803, addressed to the Secretary of the Society," The Religious Monitor, vol. I (1803): 392. 
Commander of Konstantinogorsk. The missionaries were cherishing hopes that he be offered a Russian military appointment, which, they thought, would be better than his going through Muslim religious education, in case he could not be won over outright to Christianity. ${ }^{59}$

In late 1805 , Kattı was talking about his decision to renounce Islam and to embrace Christianity. ${ }^{60}$ In the meantime, he made rapid progress in reading and speaking the English language, in addition to his native Turkish and Russian. ${ }^{61}$ In May 1806, he accompanied John Mitchell, one of the Karas missionaries, to St. Petersburg. Although he was disappointed to find out that St. Petersburg was not the center of the Presbyterian missionaries, he gave vent to his strong desire to visit that center, i. e. Edinburgh. He wrote to the Edinburgh Missionary Society with his own handwriting, in English: "I have, for some time past, had an anxious desire to visit Scotland, and to see you and the rest of the good people, of whom I have heard your friends at Karass speaking. As I am at present in St. Petersburgh, along with Mr. Mitchell, I have thought of petitioning you to allow me to come to Edinburgh, and to return to Karass, with the first of your friends whom you may send out." Kattı's wish was received most favorably by the Directors of the Missionary Society who unanimously resolved to authorize their secretary to invite him to Edinburgh. ${ }^{62}$ However, this visit would not be possible before a decade was out.

After his return to Karas, Kattı was openly declaring himself a Christian and was fervently defending his new religion against the Muslims. ${ }^{63}$ In July 1807, Katt1 was baptized ${ }^{64} \mathrm{He}$ wholeheartedly joined the missionaries' activities and began to work for the spread of Christianity among his countrymen. The latter, including his Geray relatives, were outraged by his decision and, very possibly, their grudge was checked only thanks to the Russians' protection of Katt1. ${ }^{65}$ Indeed, the Russian authorities were keen on displaying their interest in Katt1. Once he became ill, the civil governor immediately sent a physician for him. ${ }^{66}$

\section{Katt1 Geray in the Russian imperial service}

In the wake of his baptism, in summer 1807, Kattı left the mission in order to support himself materially. He went to Georgievsk where the governor employed

59. "Religious intelligence. Edinburgh Missionary Society," The Religious Monitor, vol. II (1804): 115.

60. "Extract of a letter from the Rev. H. Brunton," The Religious Monitor, vol. IV (1806): 149.

61. "Extract of a letter from Mr. Robert Pinkerton," The Religious Monitor, vol. IV (1806): 151.

62. “Edinburgh Missionary Society,” The Religious Monitor, vol. IV (1806): 311-312.

63. "Edinburgh Missionary Society," The Religious Monitor, vol. V (1807): 88-89.

64. "Report of the Directors of the Edinburgh Missionary Society," The Religious Monitor, vol. VI (1808): 472.

65. "Edinburgh Missionary Society,” The Religious Monitor, vol. V (1807): 421

66. Ibid.: 323 . 
him as a writer in the court, thus commencing his career in the service of the Russian government. ${ }^{67}$ Yet, his allowance for this job was so small that he had to be supported from the funds of the Scottish mission in Karas. ${ }^{68}$ Meanwhile, the pressures of his relatives continued on the matter of his conversion. Sultan Mengli Geray, together with his wife, expressed his indignation to Kattı and urged him to revoke his decision. The former said, "I wear Russian clothes and receive Russian money, yet I have not renounced my religion. There is nothing for which I would renounce my religion. I know not, indeed, what I might do, if I might do, if I were to be made Emperor. But there is no religion like that of the true Moslems. It is true religion, and no matter what we do, we do not renounce our religion." The Sultan expressed the disgrace they felt before their people and threatened Kattı with washing their hands of him unless the latter returned to Islam. ${ }^{69}$

All this was to no avail, however; Kattı stood fast in his decision. Moreover, he was actually thinking of converting his relatives to Christianity, being especially hopeful with regard to İslâm Geray..$^{70} \mathrm{He}$ would visit the village of Devlet Geray and enter into lengthy and impassioned discussions with the villagers about the superiority of Christianity over Islam. ${ }^{71} \mathrm{He}$ would preach to his countrymen about religious issues at every opportunity and circulate the missionary tracts in Turkish printed by the mission in Karas. ${ }^{72}$

We have little information about Kattı Geray's relations with his Geray relatives back in the North Caucasus after his departure from the region following his entry into Russian military service. It can be assumed that such ties were minimized both due to his absence and, more importantly, to his becoming an apostate outcast. Much later, in 1820, Sultan Mengli Geray would tell the Scottish missionaries who paid him a visit that, according to the Islamic law, as an infidel, Kattı Geray would no longer be eligible for the inheritance of the property of his relatives. ${ }^{73}$ In any case, except for brief visits, the rest of Kattı Geray's life would be spent outside of the North Caucasus.

In April 1809, Kattı began to serve as a Fahnenjunker in the Nizhnii Novgorod Dragoon Regiment of the Russian Imperial Army. In August 1809, he became an ensign. Since July of the same year, he had been participating in the war against the

67. "Edinburgh Missionary Society. Intelligence from Karass," The Religious Monitor, vol. VI (1808): 35 .

68. "Report of the Directors of the Edinburgh Missionary Society, to the Annual Meeting of the members of that Society, held at Edinburgh, the 19th day of April, 1808," art. cit.: 61.

69. Ibid.: 96-97.

70. "Edinburgh Missionary Society," The Religious Monitor, vol. VI (1808): 186. When İslâm Geray died in early 1809, the missionaries hoped very much that he died a Christian at heart, though there was hardly any evidence for that. Ibid., vol. VII (1809): 426-427.

71. "Edinburgh Missionary Society," The Religious Monitor, vol. VI (1808): 375-376.

72. Ibid., vol. VII (1809): 229.

73. In this information, Major General Sultan Mengli Geray is referred to as the "Priestoff [Pristav] Sultan" by the missionaries. "Scottish Missionary Society. Karass," Scottish Missionary Register(Edinburgh), vol. I, no. 6 (June 1820): 191. 
Ottomans and Persians in the Transcaucasus. He took part in the combat around Gence and Erevan. He was also present during the capture of, and evacuation from, the Ottoman fortress of Ahiska (Akhaltskhe) in 1810.74

Throughout his military career, Kattı Geray experienced quite colorful assignments. At one point, in 1815, he was commissioned by General N. R. Rtishchev, the Commander-in-chief of the Russian troops in Georgia, to command the Cossack detachment which accompanied the Persian envoy to St. Petersburg. He successfully performed his escort duty of the diplomatic convoy which also included two elephants and twenty-four stallions to be presented to the Tsar. ${ }^{75}$ This task would be the occasion on which Katt 1 Geray was first introduced to the Tsar Alexander I. ${ }^{76}$

While serving in the army, he kept in constant touch with the mission in Karas either by correspondence or by visits. In one of his letters to Brunton in 1810 , he wrote that if the war between Russia and Turkey came to an end, he could circulate missionary publications on the frontiers of the latter and send them to Erzurum and other large cities. ${ }^{77}$ While he was in Georgia, he, as usual, continued to preach Christianity to every Muslim he happened to converse with. ${ }^{78}$ In June 1813, he took a two-month home leave and came back to Karas. ${ }^{79}$ There, he expressed to the missionaries his strong desire to be employed in missionary work if he could be freed of his military engagement. While in Karas, Kattı met Karl Fuchs, the professor (later, the rector) of Kazan University, who happened to visit the mission. ${ }^{80}$ Fuchs invited him to Kazan to publish the Gospel for the Muslims in and around there. Katt1 answered in the affirmative, so long as he could be freed from the military. ${ }^{81}$

\section{The activities of the Scottish missionaries among the North Caucasian Muslims}

As for the Scottish mission in Karas, they completed the translation and printing of the New Testament in Turkish in 1813. The principal actor of this singularly major

74. TsGAARK, f. 49, op. 1, d. $5640,1.15$.

75. TsGAARK, f. 49, op. 1, d. 5640,1. 8 and 16; Reiswitz II: 125.

76. Reiswitz III: 8.

77. “Edinburgh Missionary Society,” The Religious Monitor, vol. VIII (1810): 270.

78. "Intelligence from Karass," The Religious Monitor, vol. XI (1813): 229.

79. TsGAARK, f. 49 , op. 1, d. 5640,1. 2.

80. Karl Fuchs was a naturalized Dutchman. Apart from being a very famed physician by education and practice, he was also a professor of natural history and botany. A true renaissance man, he was known for his deep knowledge of the history, ethnography, archaeology, and numismatics of the Volga region, especially those of the Volga Tatars. Fuchs was the author of a large list of books and articles on these subjects. Apparently, he spoke or read Turkic (Tatar) and Arabic too. See his biographies in, Biograficheskii slovar' professorov i prepodavatelei Imperatorskogo Kazanskogo Universiteta (1804-1904), Part I (Kazan, 1904): 367-369 and Russkii biograficheskii slovar', vol. XXI (St. Petersburg, 1901): 243-249.

81. "Intelligence from Karass," The Religious Monitor, vol. XI (1813): 418-419. 
accomplishment under very unfavorable circumstances, Henry Brunton, died a few months before the completion of the task. ${ }^{82}$ His death was a great loss to the mission in Karas.

As was reflected in the reports and letters they sent to Edinburgh, for most of their sojourn in North Caucasus, the missionaries in Karas cherished great hopes about the possible conversion of large numbers of local Muslims. They were very prone to interpret any individual interest displayed to them or the publications they distributed as initial evidence of possible conversion. Most such hopes proved to be wishful thinking at best. That they were not exposed to any direct violent hostility during their visits to the villages or meetings with the local mullahs must have much to do with either sheer curiosity or restraint due to the knowledge that the missionaries were under the protection of the Russians, rather than any serious inclination to what the missionaries preached. The tolerance of certain local chieftains such as Sultan İslâm Geray was effective too.

In fact, the local Muslims deeply resented the Tsar's grant of land, which they justly considered theirs, to the Scottish mission. Even the directors of the Edinburgh Missionary Society would admit this as the "obviously unmissionarly aspect of the settlement." This was why the "jealousy and hatred of the natives were excited against the Missionaries, from the moment of their possession of the land, under imperial grant." 83 Moreover, the missionaries' constant efforts to interfere with the religion of the local Muslims were anything but welcome. The Muslim mountaineers and Nogays were extremely indifferent to the preaching of the Scots, to say the least. ${ }^{84}$ As for the several tracts and pamphlets published and distributed by the missionaries with great hopes, not only were few people able to read them, but even fewer copies were read and kept by the literate Muslims. ${ }^{85}$ Especially the conversion of Katt 1 Geray agitated the local Muslims, particularly the Nogays, among whom Gerays represented the upper element, against the missionaries, although the latter apparently tended to overlook that fact. ${ }^{86}$ The missionaries were frequently under threat, especially on the part of the Kabardians. These Adyge mountaineers would abduct the native children, whom the missionaries were bringing up as Christians, carry away their cattle, and destroy some of the buildings. All these would induce the missionaries to seek refuge in Georgievsk, the nearby Russian fort, and to ask for Russian military guards, which they eventually obtained. ${ }^{87}$

82. W. Brown, op. cit:: 424. While translating the New Testament into his recently acquired Turkish, Brunton made a great deal of use of the mid-seventeenth century Turkish translation of the New Testament by Lazarus Seaman in England.

83. Report of the Edinburgh Missionary Society for 1818(Edinburgh, 1818): 52.

84. W. Brown, op. cit.: 422-425.

85. Ibid:: 430.

86. H. J. von Klaproth, op. cit.: 274.

87. "Otnoshenie t. s. Kozodavleva k gen. Rtishchevu, ot 29-go avgusta 1813 goda, no. 332," Akty Sobrannye Kavkazskoiu Arkheograficheskoiu Kommissieiu, vol. V (1873): 909. 
On the other hand, identification with the Russians, whose protection the missionaries sought and received, was hardly helpful for their approach to the natives, who were anything but sympathetic to Russians as invaders to their lands. 88 In a letter to the Russian authorities, Alexander Paterson, the head of the mission after the death of Brunton, complained about being compelled to conduct their work among the Nogays only, as the Kabardians proved to have a very volatile temper. He also considered the fact that the head of the Nogays, whom they considered as their primary would-be-Christians, was a Muslim, namely Major General Sultan Mengli Geray, a great obstacle to their missionary activities. ${ }^{89}$

In any case, the prospects of effective missionary work and their chances and means of reaching out to the natives were hardly increasing for the Scottish mission in Karas. This was not exactly reflected, however, in the reports of the missionaries in the field, whose enthusiasm remained seemingly intact, and who kept their spirits high in view of their overly sanguine assessments of few native individuals. The missionaries tended to believe, or rather made themselves believe, that in the area they were based, Islam was about to erode and the natives would soon be ready to receive the message of the Gospels. Whatever the suppositions of the missionaries were, they would not be confirmed by any significant movement of the native population towards Christianity.

Be this as it may, the overall circumstances were indeed changing. The demographic composition of the village during the first decade of the work of the missionaries altered radically. First, the Nogays, the original inhabitants, left the village due to political developments and plague. They were replaced by some 180 German settlers from the Saratov province. ${ }^{90}$ In 1814, there were a total of 205 inhabitants in Karas, who consisted of six Scottish, thirty German, six Christianized Circassian, and one Tatar (i.e., Nogay) families.${ }^{91}$ By then, throughout the existence of the mission, twenty-seven native slaves had been ransomed and ten of them had been baptized. Of the not-yet-baptized ransomed slaves, five died and four ran off the Kabardians, as did a baptized one too. ${ }^{92}$ It was in 1814 that the Scottish Missionary Society resolved to extend their activities, especially those of the printing and distribution of scriptures, to Astrakhan and Orenburg. Thus, Karas' status as the center of gravity of Scottish missionary work in the Russian Empire would change in favor of these two more easterly stations. Next year, when the missionary stations in Astrakhan and Orenburg were established, some of the missionaries in Karas were transferred to them. ${ }^{93}$ Since both the Missionary Society and many of the missionaries in the field consistently reiterated the significance and

88. Report of the Edinburgh Missionary Society for 1818, op. cit.: 52

89. “Otnoshenie t. s. Kozodavleva k gen. Rtishchevu... ”, art. cit.: 910.

90. M. V. Jones, art. cit.: 57 and 60-61.

91. V. Ia. Simanskaia, art. cit.: 202.

92. Thomas Smith, John O. Choules, A. M. Newport, The origin and history of missions, vol. II (Boston, 1837): 221.

93. Ibid. 
potential of the station in Karas, and they spurned the idea of abandoning it, ${ }^{94}$ there must have been arguments against its continuation. Obviously, the Society was unable adequately to supply the increased number of stations with additional missionaries.

While the mission in Karas was struggling with these troubles, Kattı Geray had long made up his mind to abandon his military career as soon as possible in order to devote himself to the spread of Christianity among his ethnic kinsmen. In fact, having fulfilled the duty of escorting the Persian envoy, he stayed in St. Petersburg until his retirement from the army. There, he was constantly under the eye of Dr. John Paterson and Robert Pinkerton, the resident Scottish missionaries there, who tried to assess whether his conduct was that of a true Christian..$^{95}$ During Katt 1 Geray's leaves from the army, the other Scottish missionaries in Karas were also able to observe his perseverance and zeal in the Christian faith and made sure that he was up to the task he was claiming.

\section{Inquiring the possibilities of missionary work in the Crimea}

It seems almost certain that, during these times, Kattı urged the missionaries to found a station in his homeland, the Crimea. As a matter of fact, the Scottish missionaries were indeed interested in the Crimea and were trying to monitor developments there concerning missionary activities. The establishment of Auxiliary Bible Societies, as local branches of the Russian Bible Society, which aimed at the translation of the Gospels to the languages of the non-Christians in Akmescit (Simferopol) and Kefe (Feodosiia) was considered a great blessing by the Scottish missionaries. ${ }^{96}$ They took serious heed of the Crimea with a vast potential for the work, where, apart from its own non-Christian population, there was the strategic potential of reaching out from there, to Anatolia, Mingrelia, Abkhazia, and to other littoral parts of the Caucasus. Conducting an invigorating work among such Christian peoples as the Greeks and Armenians of the Crimea, who had been Turkified culturally to the point of adapting Turkish as their mother tongue, was also considered. ${ }^{97}$

94. Report of the Edinburgh Missionary Society for 1818, op cit.: 12-13.

95. "Report of the Directors of the Edinburgh Missionary Society; delivered to the Anniversary Meeting, held in Bristo Street Meeting house, April 2, 1816," The Religious Monitor, vol. XIV (1816): 284.

96. The Auxiliary Bible Society in Kefe (Feodosiia) did not confine its activities of distributing the religious texts to its home town or even to the Crimean peninsula, but extended, through the Russian mission in Istanbul, its distribution of tracts to the Greek inhabitants of the Aegean islands and Anatolian littoral towns, as well as to the Christians of Mingrelia and Guria. "Ueber den gegenwärtigen Zustand der griechischen Kirche in Russland," Magazin für die neueste Geschichte der evangelischen Missions- und Bibelgesellschaften (Basle, 1819): 68.

97. "From the Rev. R. Pinkerton. St. Petersburg, June 5, 1815," The Christian Disciple (Boston), vol. IV (1816): 93-94; "Foreign intelligence. Russia," The Missionary Register for MDCCCXVI(1816): 419-423. 
Under these influences, the Scottish missionaries began to inquire into the circumstances in the peninsula. Robert Pinkerton, one of the most active Scottish missionaries in Russia, who contributed a great deal to the foundation of the Russian Bible Society, and was a former member of the mission at Karas, visited the Crimea in June 1816. Before then, while he was in St. Petersburg, Pinkerton had investigated the circumstances in the Crimea carefully. He had talked to Major General Kaya Bey Bolatukov, the commander of the Crimean Tatar cavalry regiments in the Russian army, who happened to be then in the Russian capital. ${ }^{98}$ In his conversation with Bolatukov, Pinkerton was particularly inquisitive about the approach of the Muslim Mufti in the Crimea. Bolatukov provided Pinkerton with a highly laudatory letter of recommendation addressed to the ataman of the Don Cossacks. Although a Muslim himself, Bolatukov was a contributor to the Bible Society. So were some of his relatives back in the Crimea. ${ }^{99}$

While he was in the Crimea, Pinkerton actively cooperated with the local Auxiliary Bible Societies. He participated in the pompous opening ceremony of the Crimean Auxiliary Bible Society in Akmescit, on 12 June $1816 .{ }^{100}$ Besides the projects of evangelizing the Crimean Tatars, he was also interested in possible missionary work among the Turkic-speaking Karaim, making use of the tracts published in Turkic by the Scottish missionaries. ${ }^{101}$ From a Karay in Bahçesaray, Pinkerton purchased a Karaim Turkic version of the Old Testament (in Hebrew characters). This manuscript would be useful to the Scottish missionaries who were working on a Turkic translation of the Old Testament. ${ }^{102}$

98. Kaya Bey Bolatukov, a high ranking Crimean Tatar nobleman, was a veteran of the Napoleonic wars and a highly respected Crimean Tatar officier of the Russian Imperial Army with several decorations for his heroic and loyal services. Krymskii konnyi Ee Velichestva Gosudaryni Imperatritsy Aleksandry Feodorovny polk (San Fransisco, 1978): 21.

99. Extracts of letters from the Rev. Robert Pinkerton, on his late tour in Russia, Poland, and Germany; to promote the object of the British and Foreign Bible Society (London, 1817): 1-2; "Foreign intelligence. Russia," The Missionary Register for MDCCCXVI (1816): 422-423. In his letter of introduction to the ataman of the Don Cossacks, Kaya Bey Bolatukov commended the missionary zeal of Pinkerton by saying that Pinkerton "had brought him almost to embrace Christianity." Extracts of Letters from the Rev. Robert Pinkerton..., op. cit.: 2 .

100. Extracts of Letters from the Rev. Robert Pinkerton..., op. cit.: 16-17. According to Pinkerton, out of 200 early members of the auxiliary society, 76 of them were Muslims, i.e., Crimean Tatars. It is almost certain that these belonged to the highest ranking mirza families (i.e., Crimean Tatar "nobility"), just like the Bolatukovs, who, though remaining staunch Muslims, were keen on making gestures of fidelity to the Russian state.

101. E. Henderson, op. cit.: 332.

102. Extracts of Letters from the Rev. Robert Pinkerton..., op. cit.: 18-19; "Report of the Edinburgh Missionary Society," The Missionary Register for MDCCCXVII (London, 1817): 493. For the origins and nature of this manuscript of Old Testament in Karaim Turkic, see Dan Shapira, Avraham Firkowicz in Istanbul (1830-1832) (Ankara, 2003): 30. Pinkerton, apparently, displayed a special interest in the Karaim and their being Turkic speakers. When he visited Lithuanian parts of the Russian Empire, in Trakai, he met with the local Karays. Pinkerton was fascinated when he communicated with them in Tatar (Turkic) which they had preserved despite the fact that they had left the Crimea five centuries ago. He must have considered the use of Turkic language tracts useful in evangelizing not only among Muslim Turks but also among the Karays. "Russia. Bible Society," The Missionary Register for MDCCCXVIII (1818): 478. 
In June 1816, Alexander Paterson of Karas also made a tour in the Crimea to look at the possibilities there. There, he especially busied himself with distributing copies of the Turkic New Testament. He returned to Karas with revived hopes on 18 July 1816. The interest displayed by some individuals of Muslim and Judaic (possibly Karaim) faith in having copies of the Turkic translation of the New Testament induced him to consider the Crimea as a promising field for missionary activities. ${ }^{103}$

Following the visits of Paterson and Pinkerton, the Scottish missionaries tried to supply the Crimean auxiliary Bible societies with publications. In addition to the dispatch of copies of the Turkish New Testament and tracts from Karas to the Simferopol (Akmescit) Auxiliary Bible Society, 150 copies of the Book of Psalms in Turkish were also sent from the Scottish mission in Astrakhan. All these publications, of course, were meant primarily for the Crimean Tatars. The Directors of the Edinburgh Missionary Society considered it "absolutely necessary [...] to provide some suitably qualified missionaries" to work in the Crimea. Yet there was a serious shortage of missionaries elsewhere in the stations of the Society, primarily in Karas. Therefore the opening of the station of the Edinburgh Missionary Society in the Crimea could not be realized before Karas was reinforced with additional laborers. ${ }^{104}$ Actually, five more years would be needed to open a station in the Crimea following the visits of Paterson and Pinkerton. Before then, Kattı Geray would also travel to the Crimea for the purpose of studying the possibilities there in 1817.

\section{Kattı Geray devotes himself to missionary work}

Before the Scottish missionaries' visits to the Crimea, Katt1 Geray had requested his retirement from the army. Thereupon, with the special order of Alexander I, he retired from military service "on the grounds of health" with the rank of first lieutenant on 14 January 1816.105 Possibly it was during the process of Katt1 Geray's retirement from the army that a warm friendship developed between Kattı Geray and Alexander I. The mystic nature of Alexander and the zeal and idealism of the Christian Kattı Geray, as a descendant of a celebrated Muslim dynasty, must have contributed a great deal in the growth of amity between them.

103. "Edinburgh Missionary Society," The Religious Monitor, vol. XIV (1816): 345-346; "Account of Mr. Paterson's journey to the Crimea," Ibid., vol. XV (1817): 446-450; T. Smith, J. O. Choules, A. M. Newport, op. cit.: 221-222; "Report of the Edinburgh Missionary Society," The Missionary Register for MDCCCXVII (1817): 494-497; "Auszug aus dem Journal einer Reise des Herrn Alexander Paterson, Mitgliedes der schottischen Kolonie, durch die Krimm, im Verlaufe des Jahres 1816," Magazin für die neueste Geschichte der evangelischen Missions- und Bibelgesellschaften (Basle, 1819): 105-115.

104. Report of the Edinburgh Missionary Society for 1818, op cit.: 34-35.

105. TsGAARK, f. 49, op. 1, d. 5640,1.2. 
While Katt1 Geray was processing his petition of retirement, the Scottish missionaries encouraged him and made exertions in his obtaining an honorable discharge. It was also decided to train him as a missionary with a proper theological education. ${ }^{106}$ As the best place for such an education was the center of Scottish missionary work, it was planned to move him to Edinburgh. Sympathetic to these designs, the Tsar undertook the expenses of his visit to Scotland and the means of his support in Britain, by bestowing upon him a handsome annual salary of 6,000 rubles. ${ }^{107}$ Thus Katt1 Geray left Russia for Scotland in autumn 1816. ${ }^{108}$

\section{Kattı Geray in Scotland}

There is not much information about the activities of Katt1 Geray during his first visit to Scotland. Still, there can be little doubt that he was warmly received in missionary circles. After all, being one of the few converts of the Scottish missionaries in the Russian Empire, and certainly the most celebrated one, Kattı Geray's previous activities had been covered quite extensively by the British religious press. He had already become "a character well known to the religious public of Britain." 109 In any case, Katt 1 Geray's devotion to the Christian cause deeply impressed the Directors of the Edinburgh Missionary Society, who considered him as "a promising instrument of eminent usefulness to his countrymen." With their consent, Kattı Geray visited London. In the British capital, he met the tutors of the Old Homerton College, where he began to conduct his studies. ${ }^{110}$

While in Britain Katt1 Geray had in mind a project aimed at launching a missionary educational enterprise in his homeland, the Crimea. His project involved the establishment of a seminary for Muslim youth from the Crimea and beyond. The prospective graduates of this seminary would return to their respective homelands to proselytize their kinsmen. As became clear by subsequent developments, he considered the Crimea as the pilot field of the first experiment of an enterprise, which would involve all Muslims of the Russian Empire. He

106. "Report of the Directors of the Edinburgh Missionary Society; delivered to the Anniversary Meeting, held in Bristo Street Meeting house, April 2, 1816," The Religious Monitor, vol. XIV (1816): 284.

107. "Kattegary, ein tartarischer Sultan, bildet sich zum Lehrer des Christenthums für seine Nation," Magazin für die neueste Geschichte der evangelischen Missions- und Bibelgesellschaften (Basle), vol. III (1818): 39.

108. Report of the proceedings of a General Meeting held 4th of August, 1819, at the Rotunda for the purpose of establishing an Hibernian Missionary Society for Tartary and Circassia; with an address from the Committee to the public, and an Appendix (Dublin, 1819): 18 (Courtesy of Ömer Turan).

109. E. Henderson, op. cit.: 299. With regard to Kattı Geray, the Scottish Missionary Society would "give thanks, as one of the first and most distinguished fruits of their Mission." "Brief account of the origin, progress, and present state of the Scottish (formerly the Edinburgh) Missionary Society," Scottish Missionary Register, vol. I, no. 1 (January 1820): 17.

110. Report of the proceedings of a General Meeting held 4th of August, 1819...," op . cit.: 19. 
assumed, quite possibly, that respect towards his genealogy among the local population would facilitate such work there. The particulars of this enterprising, if naive, plan must have taken shape in his mind in the course of his conversations with the Tsar and the Scottish missionaries.

In order to present his project to the Tsar, he returned to the Russian Empire from Scotland. Before giving final shape to his project, he opted to inquire into circumstances in the Crimea. Thus, accompanied by the Reverends Lewis Way and Nehemiah Solomon (apparently a former Rabbi from Poland), Kattı Geray proceeded from Moscow to the Crimea via Odessa in $1817 .{ }^{111}$ In the Crimea, Katt1 Geray essentially looked into the feasibility of a Christian school for the Muslims there. ${ }^{12}$ Like the Scottish missionaries who preceded him, Kattı Geray distributed as many Turkish New Testaments to the local Crimean Tatars as possible. ${ }^{113}$ In Bahçesaray, they attended the prayers of the Muslims and conversed with the local Muslim clergy at length. Throughout this journey, Kattı Geray made a very good impression on his companion Lewis Way who, in his person, saw "a most promising evidence of the possibility of converting Mahomedans."114

Kattı Geray finally presented the outlines of his project to Alexander I in February 1818. There, he stated his objective as "the spiritual, and consequently the temporal amelioration of his countrymen." 115 Soon after submitting his project, Kattı Geray travelled to Edinburgh via London. It was shortly after his arrival in Britain that the Tsar expressed his approval of the young Sultan's project through a letter of Prince Golitsyn. ${ }^{116}$ Alexander I also promised every necessary assistance in carrying the project into effect. ${ }^{117}$

During his second stay in Scotland, Kattı Geray must have furthered his religious studies. According to an account, Kattı Geray was enrolled in the University of Edinburgh, in all likelihood to study divinity. ${ }^{118}$ Certainly, while in Edinburgh, Kattı Geray expressed his grandiose designs to the missionary and religious dignitaries and circles under whose auspices he was conducting his studies. He would make enthusiastic speeches at missionary meetings, exhorting

111. "Extracts from the journal of Rev. Nehemiah Solomon, kept during his journey from Moscow to Odessa, in company with the Rev. L. Way, and the Sultan Katteghery," The Religious Monitor, vol. XVI (1818): 386; Mary Holderness, New Russia. Journey from Riga to the Crimea, by way of Kiev with some account of the colonization, and the manners and customs of the colonists of New Russia (London, 1823): 128.

112. M. Holderness, op. cit.: 128.

113. "Edinburgh Missionary Society," The Religious Monitor, vol. XVI (1818): 463.

114. Report of the proceedings of the sixth anniversary of the Hibernian Missionary Society, hold in the Rotunda, in Dublin, on Friday, 21st April, 1820 (Dublin, 1820): 18.

115. Report of the proceedings of a General Meeting held 4th of August, 1819...," op cit.: 73 .

116. Ibid.

117. "Brief account of the origin, progress, and present state of the Scottish (formerly the Edinburgh) Missionary Society," art. cit.: 23.

118. J. B. P., art. cit. 
the audience about the exigency of speeding up the work among his countrymen. He would lay particular stress upon his school project. ${ }^{119}$

He formally presented his project to the Directors of the Edinburgh Missionary Society, as the "Sketch of an Institution to be established in the Krimea, for the instruction of the children of the different Tartar tribes and Circassian nations in the knowledge of the true Messiah, Jesus of Nazareth, with the design to raise up native school-masters and teachers of the word of God." According to this detailed version of his project, the proposed institution would be under the management and control of four Christian teachers to be supplied by the Edinburgh Missionary Society. Two of these teachers would be employed as preachers in the Crimea and the Caucasus. Kattı Geray would be considered as belonging to the institution, with a vote in the council of missionaries and would voluntarily engage himself in furthering the work of the association. The children offered by their parents to the institution for a period of not less than three years were to be received freely and every care should be taken to "enlighten their minds by teaching them to read, and as far as possible, encouraging the reading of the Scriptures throughout the Nations." 120 Next to the institution, it would have been essential to establish a printing press with Arabic types for the publication of religious and other useful tracts, as well as to operate a loom for weaving to forward objects of industry. ${ }^{121}$

No matter how enthusiastic Kattı Geray might be about realizing his designs in the Crimea, and even all over the "Tatar" (i.e., Turkic) world, the Edinburgh Missionary Society was badly in need of resources. The maintenance of the increasing number of missionary stations in the mostly Muslim parts of the Russian Empire had drained the resources of the Society. It was critically short of funds for keeping the already established stations, let alone for indulging in any further adventures, such as the one proposed by Kattı Geray. For the purpose of fund raising, the Society was sending deputations outside Scotland. ${ }^{122}$ Therefore, the sympathies of the Society notwithstanding, Kattı Geray could not count upon much support on the part of the Society other than a moral one. Whatever funds he needed, he should provide primarily with his own efforts either in Britain or in Russia, certainly on the recommendation of the Edinburgh (later Scottish) Missionary Society.

119. "Edinburgh Missionary Society," The Religious Monitor, vol. XVI (1818): 463.

120. Report of the proceedings of a General Meeting held 4th of August, 1819...," op. cit.: 11; Report of the Scottish Missionary Society for 1820 (Edinburgh, 1820): 74.

121. Report of the proceedings of a General Meeting held 4th of August, 1819...," op. cit.: 1213. Had this project been realized, this printing house would have been the first of its kind among the Crimean Tatars. As a matter of fact, the first typography with Arabic type was established in the Crimea (Bahçesaray) by İsmail Bey Gaspıralı in 1883.

122. Such a deputation visited London and engaged in a number of fund raising meetings in March 1819. "Edinburgh Missionary Society. Proceedings of the deputation to London," The Missionary Register for MDCCCXIX (1819): 134-135. 


\section{Katt1 Geray in Ireland}

In summer 1819, sponsored by the Scottish Missionary Society, Kattı Geray travelled to Ireland to solicit support for his project. The Scottish Missionary Society introduced him to the Irish public with a strong letter of recommendation. There, wholehearted support for his project was expressed, as well as the Society's decision to establish a station in the Crimea. It was pledged that, even if the proposed seminary could not be realized, the Scottish missionary station in the Crimea would continue to function. ${ }^{123}$ Evidently, Katt1 Geray's project engendered a lively interest in Irish circles. This led to the decision to establish an "Hibernian Missionary Society for Tartary and Circassia," whose center of operations would be in the Crimea, with the aim of sending missionaries to these lands. The formative meeting of this society was held on 4 August 1819 in Dublin, where Kattı Geray made a lengthy speech introducing his aims and project. During this meeting, it was resolved unanimously "that, as the Scottish Missionary Society has engaged to furnish the Sultan Katte-Ghery [Kattı Geray] with four Missionaries, in furtherance of his plan, and is now employed in propagating the gospel in parts of Tartary and Circassia, the funds of this society shall, for the present, be transmitted to the treasurer of that body, for the purpose of being applied to the specific object of this association." 124

Following his tour in Ireland, Kattı Geray visited Dumfries in Scotland, where a public meeting was held with his presence on 4 October 1819 . He made a speech outlining what the Scottish Missionary Society had already accomplished among the Muslims of the Russian Empire as well as projects for the near future. Obviously, the objective was providing financial support for all these projects for which no other funds were currently available. The meeting was not fruitless, as it resolved to form a local branch society for the projects of the Scottish Missionary Society which came into existence within eleven days. ${ }^{125}$ Kattı Geray then proceeded to Dundee and Cupar where he repeated his pleas before large audiences who contributed to the fund raising. Throughout all these speeches Kattı Geray was keen on stressing that "there were no fewer than eighty millions of Tartars, thousands of whom were daily perishing in ignorance and Mahommedan delusion." 126 Obviously, with this he meant the overall body of Tatars, i.e. Turks (or Turkic peoples) in the Russian Empire and even beyond, possibly including those

123. Report of the proceedings of a General Meeting held 4th of August, 1819...," op. cit.: 17.

124. "Ireland. Hibernian Missionary Society for Tartary and Circassia," Scottish Missionary Register, vol. I, no. 1 (January 1820): 7; "Scottish Missionary Society. Formation of the Hibernian Society for Tartary and Circassia," The Missionary Register (April 1820): 153; Report of the Scottish Missionary Society for 1820 (Edinburgh, 1820): 72-73.

125. "Dumfries and Galloway Branch of the Scottish Missionary Society," Scottish Missionary Register, vol. I, no. 3 (March 1820): 71-72; Report of the Scottish Missionary Society for 1820 (Edinburgh, 1820): 70.

126. "Dumfries and Galloway Branch...," art. cit.: 72-73; "Scottish Missionary Society. Formation of Dumfries and Galloway Branch," The Missionary Register(April 1820): 153. 
in the Ottoman Empire too. Even with the inclusion of the latter, however, Katt1 Geray's figure constituted a gross exaggeration. Be this as it may, it must have been the most striking part of the speeches which attracted the attention of his audiences who had little, if any, information about those parts of the world.

\section{Kattı Geray marries a Scottish girl}

Engulfed by ambitious designs for the conversion of his people, Kattı was contemplating a marriage for himself which would primarily serve his ideals. Thinking that the Muslim women were enslaved by their husbands in the harems, he was planning, after the completion of his studies, to return to the Crimea and to make an exemplary marriage there with a brave and intelligent woman who would teach Christianity to Tatar women. ${ }^{127}$ Fate, however, had a different matrimonial future in store for him. During his stay in Edinburgh, Kattı met and fell in love with Anne Neilson. The latter was the fourth daughter of James Neilson, a Scottish gentleman who was said to have made a fortune in the Indies. ${ }^{128}$

The couple married on 26 April 1820, at the St. Cuthbert Church in Edinburgh. ${ }^{129}$ The marriage created a great sensation within local Scottish society. A romance involving an oriental prince inevitably led to the circulation of fanciful, exotic stories. Katt1 Geray was imagined by many locals as something like a Mogul prince with incalculable wealth and a large number of retainers. One Edinburgh newspaper would write that

this sensible, well-informed, and enterprising chief is anxious to carry with him to the wilds of the Caucasus [...] that species of information which will tend to civilise his rude subjects, and we understand it to be his intention to make this subordinate to the grand plan he has formed of introducing into his native land the light of Christianity. ${ }^{130}$

On the other side, James Neilson could hardly reconcile himself to the marriage of his daughter to an oriental man, albeit a princely and Christian one who spoke English fluently. Upon Anne's determination to marry Kattı and follow him to the Crimea, James Neilson disinherited his daughter. ${ }^{131}$

\footnotetext{
127. A. Sokol, op. cit.: 12 .
}

128. J. B. P., art. cit. Of course, the stories which circulated in Russia much later that he married the daughter of the famous Admiral Lord Horatio Nelson had nothing whatsoever to do with reality. For such allegations, see V. A. Alekseev, art. cit.: 453; also in Roza Ayırçinskaya, "Zhili-byli Sultan i Sultansha...," Golos Kryma (Akmescit/Simferopol), 8 September 1995.

129. Reiswitz I: 27; Reiswitz II: 126.

130. J. B. P., art. cit.

131. Robert Lyall, Travels in Russia, the Krimea, the Caucasus, and Georgia, vol. I (London, 1825): 238; A. Sokol, op. cit.: 14. Later, however, James Neilson added to his will some material support for his daughter. Reiswitz I: 27-28. 
Following their wedding, the Sultan-Kırım-Geray couple left Scotland for Russia from Leith by sea. ${ }^{132}$ They arrived in St. Petersburg in September 1821.133 At the Russian capital, Kattı Geray busied himself with the necessary contacts concerning his project and waited for an audience with the Tsar, who was then out of town. ${ }^{134}$ During his stay in St. Petersburg, the friendship and good offices of Prince Aleksandr Golitsyn, the Minister of Religious Affairs and People's Education and the President of the Russian Bible Society, was particularly important. At least for the initial period, it was Prince Golitsyn who provided Katt1 Geray with money from his own purse to subsist there. ${ }^{135}$

\section{The Scottish mission in the Crimea and Kattı Geray}

Before Katt1 Geray was able to proceed to the Crimea, the work of the Scottish mission had already commenced there. As Kattı Geray's project received the Tsar's sanction with the promise of all requisite financial assistance for its realization, the Scottish Missionary Society had resolved to send three of its missionaries to set up a station in the Crimea. ${ }^{136}$ The Society, certainly encouraged by Katt1 Geray, deemed that there was "ample scope for Missionary work among the great body of the population there; - many of whom seem to be waiting for some messengers of God, to explain to them what they have already read, with the utmost eagerness and interest, (in the Tartar Testament which has been extensively circulated among them) concerning Jesus, the true Messiah, and the only Saviour of sinners."137 Mary Holderness, a British lady who was resident in the Crimea between 1816-1820, was very optimistic too. She thought that Kattı Geray's involvement might be expected to have great weight and influence in enhancing the missionary cause among the Crimean Tatars. She harbored little doubt that the confidence of the Crimean Tatars could be won easily and once the schools Kattı Geray had contemplated would be

132. "Survey of missionary stations. Crimea. Scottish Missionary Society," The Missionary Register for MDCCCXXI(1821): 34.

133. "From Anne Sultan-Kırım-Geray (née Neilson) to her mother, dated 23 September 1820, St. Petersburg," the copy in the possession of the author (Courtesy of Wenzel Freiherr von Reiswitz).

134. "From Kattı Geray Sultan-Kırım-Geray to James Neilson, dated 28 September 1820 , St. Petersburg," copy in the possession of the author (Courtesy of Wenzel Freiherr von Reiswitz).

135. "From Kattı Geray Sultan-Kırım-Geray to his mother-in-law, dated 7 January [1821], St. Petersburg," copy in the possession of the author (Courtesy of Wenzel Freiherr von Reiswitz).

136. "Scottish Missionary Society. Facts taken from the Report of 1821," The Missionary Herald (Boston), vol. XVIII, no. 9 (September 1822): 302. For the subcriptions and donations which were collected in Scotland on the account of the mission in the Crimea, see Report of the Scottish Missionary Society for 1820 (Edinburgh, 1820): 97-99.

137. "Brief account of the origin, progress, and present state of the Scottish (formerly the Edinburgh) Missionary Society," art. cit.: 23. 
opened "a more abundant harvest may be hoped for from the Crimean Tatars than any other of the Mahommedan subjects of Russia."138

Kattı Geray's involvement in the Crimean station of the missionaries was important for the Russian authorities too. In his letter to the Scottish Missionary Society Prince Aleksandr Golitsyn wrote :

His Imperial Majesty is pleased to find in him such a desire to render himself useful to his countrymen, and hopes that acting under the direction of prudent and experienced men, he may become eminently so. As long as he exerts himself for the benefit of his countrymen in an active, prudent, and Christian manner, he may depend on the assistance of His Imperial Majesty, and on being supported by Him. But in regard to his acting as agent either for your Society or the Russian Government this must be a subject for future consideration and arrangement. It is not clear how he can act as Agent for both. As the term of his residence in Britain is nearly expired, it will be requisite that he returns to Russia as soon as possible in order that everything may be settled respecting his effective operations? ${ }^{139}$

Evidently, the Society had overly farfetched hopes concerning the fruits of the previous distribution of the tracts in Turkic in the Crimea and their effects on the Crimean Tatars. The initial intention of the Society was to send the Reverend J. J. Carruthers, "a young man of great promise" in the company of William Brown, the author of the history of missions who volunteered to work in the Crimea. Jacob Galloway from Karas was also planned to join them. According to the plan of the Society, the Scottish missionaries were to select a most suitable site in the Crimea for acquiring Turkic (in the sense of both Crimean Tatar and Turkish), for circulating copies of the New Testament and tracts, and for directing the attention of the natives. On that place, the buildings for the Seminary which was contemplated by Kattı Geray, would be built at the expense of the Russian government. The missionaries would run the Seminary upon its completion. Of the four contemplated missionaries of the Society in the Crimea, two would be engaged in the education of the pupils and the other two would travel around the peninsula for the spread of Christianity and to publish relevant materials. ${ }^{140}$

The initial plans for the personnel of the Crimean station would change, as it proved impossible for William Brown to leave Britain then. Instead, it was decided to send William Glen from Astrakhan and Dr. Ross from Orenburg to accompany Carruthers in the Crimea. It was also expected that Kattı Geray, under the patronage of the Tsar, would join them. ${ }^{141}$ While nurturing great hopes for the prospective station in the Crimea, the Scottish Missionary Society was suffering from the "more

138. M. Holderness, op. cit:: 128.

139. "Correspondence with missionaries in the Crimea. From Prince Aleksandr Golitsyn to the Directors of the Scottish Missionary Society, St. Petersburg, 5 May 1820," National Library of Scotland (Edinburgh), Manuscripts, MS.8984: 3.

140. "Brief account of the origin, progress, and present state of the Scottish (formerly the Edinburgh) Missionary Society," art. cit.: 23-24.

141. "Scottish Missionary Society. Home proceedings," Scottish Missionary Register, vol. I, no. 8 (August 1820): 271. 
than exhausted state" of its funds. As a matter of fact, the Society brought forward the issue of the importance and urgency of the prospective station in the Crimea to expedite fund-raising among its supporters at home. ${ }^{142}$

The Crimean station was established in spring 1821, that is, at a time when Katt1 Geray was still in St. Petersburg. Reverend J. J. Carruthers and his wife came to the Crimea on 8 May 1821, together with one of the ransomed youths in North Caucasus, who had been christened as "James Peddie." 143 They were joined by Dr. Ross with William Glen on 15 June of the same year. Glen was to stay temporarily as a counsellor during the foundation stage of the Crimean station. Interestingly, the missionaries established their headquarters in Bahçesaray, the ancient capital of the Crimean khans, instead of Akmescit (Simferopol), the administrative center of Russian rule in the Crimea. ${ }^{144}$ Possibly, Bahçesaray's picturesque setting, its being host to deep-rooted religious-educational institutions of Crimean Tatars, Judaic Karays (Karaim) and Krymchaks, as well as Greeks, must have played a role in their decision. Also, in comparison with the other towns in the peninsula, Bahçesaray had maintained its Tatar, i.e., Turkic/Muslim, appearance and demography more than anywhere else.

Based in Bahçesaray, the missionaries made several excursions to the other parts of the Crimean peninsula. They were principally distributing the translations of the Old and New Testaments. In this, they received the active support of the British Missionary Society, the Russian Bible Society, and the Tavrida Auxiliary Bible Society. ${ }^{145}$ Apparently, apart from the Crimean Tatars, they also targeted the Judaic, Greek and Armenian inhabitants of the Crimea. Though they were encouraged initially by the interest displayed by some Crimeans in their publications, soon many people began to react in a less than receptive manner and returned the scriptures. The Greeks were particularly hostile, as they would even denounce the missionaries to the Crimean Tatars as infidels and pronounce the books they circulate impositions. ${ }^{146}$

142. "Scottish Missionary Society. State of the funds," Scottish Missionary Register, vol. I, no. 2 (February 1820): 69-70.

143. "Crimea," Scottish Missionary Register, vol. II, no. 7 (July 1821): 244; "Survey of the Protestant missionary stations throughout the world. Crimea," The Missionary Register (February 1822): 42.

144. “Crimea," Scottish Missionary Register, vol. II, no. 9 (September 1821): 322; Walter Chapin, The Missionary Gazetteer, comprising a view of the inhabitants, and a geographical description of the countries and places, where Protestant Missionaries have labored (Woodstock, 1825): 117; T. Smith, J. O. Choules, A. M. Newport, op. cit.: 226.

145. W. Chapin, op. cit. : 117; T. Smith, J. O. Choules, A. M. Newport, op. cit.: 226. Sometime in 1821, another Scottish missionary Ebenezer Henderson visited his three missionary countrymen in Bahçesaray, whereupon he made an excursion around the peninsula both to survey the local people and to distribute tracts (Later he published his memoirs and impressions of the Crimea). E. Henderson, op. cit.: 305.

146. Charles Williams, The Missionary Gazetteer; comprising a geographical and statistical account of the various stations of the Church, London, Moravian, Wesleyan, Baptist, and American, Missionary Societies (London, 1828): 204; Report of the Scottish Missionary Society for 1823 (Edinburgh, 1823): 24. 
The distribution of the scriptures was but one of the objects of the excursions in the Crimea. A primary task lying before the Scottish mission in the Crimea was to find a suitable location for the contrived experimental seminary, the pet project of Kattı Geray, as well as to inquire into the conditions of the native peoples with regard to education. To provide the support of the Muslim clergy for the seminary or at least to prevent their opposition, the missionaries approached local mullahs. Not surprisingly, they presented the enterprise to the mullahs not as a missionary seminary but as a modern educational institution in which Turkish and Russian languages, as well as natural and social sciences and even some branches of European literature, would be taught. As such, the mullahs they contacted did not seem to be against it. ${ }^{147}$ They also contacted Major General Kaya Bey Bolatukov who expressed his approbation of their plans and his intention of committing two of his sons to their care. ${ }^{148}$

Meanwhile, Alexander I promised all requisite pecuniary assistance for the realization of Kattı Geray's project. The Tsar pledged to undertake the rent of the Experimental School building and the board of the children, provided the plan of Katt1 Geray's Experimental School succeeded and the native Crimean Tatar Muslims were persuaded to allow their children to reside with, and be educated by, the missionaries. Following the realization of these first steps, Alexander I promised to order the foundation of the Seminary without delay. A missionary source from St. Petersburg, with reference to the interview between Alexander I and Kattı Geray, recorded:

His imperial majesty, with all the kindness and affection of a genuine Christian, encouraged the young sultan to press on in the ways of the Lord, assuring of his support and protection; and concluded by saying something like this, "You must expect trials in your work. Every man who opposes errors will have trials; but if you should be so happy as to bring one Tartar to the faith of Christ, you will be well repaid for all your toil." 149

Having been obliged to wait in St. Petersburg for the determination of some of the arrangements of the Tsar, ${ }^{150}$ Kattı Geray would finally arrive in the Crimea only in late November 1821. He spent a month with Carruthers in Bahçesaray and then moved to Akmescit. He would be in charge of the prospective seminary. However, the missionary base in the Crimea displayed little progress. Following Glen, Dr. Ross also moved to Astrakhan, and Carruthers remained alone in Bahçesaray. ${ }^{151}$

147. Report of the Scottish Missionary Society for 1822 (Edinburgh, 1822): 55

148. Ibid.: 57; “Crimea,” Scottish Missionary Register, vol. II, no. 10 (October 1821): 368.

149. T. Smith, J. O. Choules, A. M. Newport, op. cit.: 226; "Survey of the Protestant missionary stations throughout the world. Crimea," art. cit.: 42; Report of the Scottish Missionary Society for 1821 (Edinburgh, 1821): 22.

150. "Survey of the Protestant missionary stations throughout the world. Crimea," art. cit. : 42.

151. Ibid. 
Carruthers was trying hard to master the Crimean Tatar language and reach out to the Muslims. Indeed, within two years he became able to preach in Crimean Tatar. ${ }^{152}$ Nevertheless, his calls for Christianity found few receptive ears among the Crimean Tatars. His wife's endeavors to instruct the Crimean Tatar women were also prevented, possibly due to a less than sympathetic reaction. Still, Carruthers managed to baptize a Crimean Tatar named Mehmed, in August 1823. Soon after, three other Crimean Tatars agreed to be taught by Carruthers and later they were baptized too. Nevertheless, these sole fruits of the missionary work in the Crimea proved anything but steady. Mehmed soon conducted himself inconsistently and his belief in Christianity would become doubtful to say the least. ${ }^{153}$ As for the other three, the situation was little different. Two of them would behave in such a way that the missionaries would reject them as having been "unworthy of the Christian Name and disgraceful to our holy religion." As for the last convert, he had been Kattı Geray's slave, who thereupon freed him. Upon gaining his freedom the man immediately returned to Katt1 Geray in the capacity of a servant. ${ }^{154}$

As a matter of fact, these rickety conversions would be the beginning of the end, rather than of future success, for the Scottish mission in the Crimea. If by nothing else, local Crimean Tatar society was appalled and outraged by these cases and, having thus realized the real purpose of the presence of the Scots there, its attitude towards them changed immediately. ${ }^{155}$ Now, if the missionaries ever had any genuine chance of reaching out to Crimean Tatar society, this was utterly destroyed.

As was the case elsewhere where the Scottish missionaries operated, Carruthers too sadly misinterpreted their reception by the Muslims of the Crimea. Initially, they were indeed warmly received by some Crimean Tatars, but as the Society also admitted, such cases of favorable reception "in almost every instance, proceeded either from ignorance of his object, from curiosity, or from fear; the Tartars in general having the idea that he was in some way or other connected with the Russian Government - a circumstance, which, though it obtained for him external marks of attention and respect, was very unfavorable in regard to the reception of his message."156

The interest displayed by the Crimean Tatars towards the scriptures distributed by the missionaries and their words about Jesus were not entirely incompatible with their beliefs and traditions. No matter what the fundamental differences were, Muslims deeply revered Jesus as a prophet and the New Testament as the word of God, albeit that the current version was a distorted one. Beyond that was a different matter. This was clearly not manifest to Carruthers. Moreover, some Crimean Tatars' acceptance of the scriptures had to do with Carruthers' statements that he

152. "Crimea," Scottish Missionary and Philantrophic Register (Edinburgh), vol. IV, no. 9 (September 1823): 494.

153. C. Williams, op. cit.: 204; "Scottish Missionary Society. Discouragements to missionary labours among Mahomedans," The Missionary Register for MDCCCXXIV (1824): 551; Report of the Scottish Missionary Society for 1824 (Edinburgh, 1824): 19.

154. "Scottish Missionary Society,” The Missionary Register for MDCCCXXV (1825): 391.

155. "Scottish Missionary Society. Discouragements...," art. cit.: 552.

156. “Scottish Missionary Society,” The Missionary Register for MDCCCXXV (1825): 391. 
had been on the Emperor's business. Even then, when the local Crimean Tatars felt obliged to accept the books, usually they either returned them to him soon or gave them to the police saying that they were unintelligible and unnecessary. ${ }^{157}$ As Carruthers conceded:

For more than a twelvemonth past, I have not given away a single copy of the New Testament or any religious publication whatever, in my immediate neighbourhood. This has not arisen, however, from any reluctance on my part to give; but from the aversion of the people to receive the gift. Nor have I, during the last twelvemonths, distributed in all five copies of the Scriptures. The truth is, the people will not receive them, now that they are aware of the nature of their contents. ${ }^{158}$

Polite and warm as they might have been initially, once Carruthers' real intention became clear to the local Crimean Tatars, the attitude of the latter changed radically. People almost totally shunned him and in the street he could find very few Crimean Tatars who would be willing to talk to him. ${ }^{159}$ Carruthers would lament failing to find a single Muslim who would admit taking any of the religious publications "distributed" by him in the course of a whole year. ${ }^{160}$

The fate of Mrs. Carruthers' enterprise was no different: At first, she had good relations with the Crimean Tatar women who frequently visited her. Then she initiated her project of teaching Muslim children. In order to lure pupils, their parents would be "compensated" for the loss of their children's labor, which was quite an attractive sum. Indeed, some poor parents did ask that their children be instructed by Mrs. Carruthers. ${ }^{161}$ When Mrs. Carruthers attempted to introduce the Scriptures into her lessons, however, the behavior of the parents changed entirely. They would instantly flee from her instead of welcoming her with a smile as they had done previously. Certainly, the alarming news of the baptism of the above-mentioned Muslims was directly responsible for the ostracism of Carruthers by the Crimean Tatars. ${ }^{162}$

In addition to the utterly unfavorable stand of the Crimean Tatars, the sympathy of the Russian officialdom towards the Scottish or other Protestant missionaries in the Russian Empire grew thinner during the first half of the 1820s. Thus, Carruthers described the circumstances under which he tried to work as "very discouraging" in

157. Report of the Scottish Missionary Society for 1823 (Edinburgh, 1823): 23.

158. "Crimea," Scottish Missionary and Philantrophic Register (Edinburgh), vol. VI, no. 5 (May 1825): 200.

159. "Survey of missionary stations. Baktcheserai," The Missionary Register for $\operatorname{MDCCCXXIV(1824):32.~}$

160. Report of the Scottish Missionary Society for MDCCCXXV (Edinburgh, 1825): 16; "Scottish Missionary Society," The Missionary Register for MDCCCXXV (1825): 391.

161. The Scottish Missionary Society had approved Carruthers' design of "compensating” the parents for persuading them to submit their children to the missionaries' instruction. However, given the financial shortcomings of the Society, this permission was restricted to a few youths. The Missionary Register for MDCCCXXV (1825): 32-33.

162. "Scottish Missionary Society. Discouragements...," art. cit.: 552. 
view of the political restraints he faced in the Crimea. ${ }^{163}$ Among others, the tsarist police would no longer allow the missionaries to baptise their converts. In such rare cases, the converts were led to join the Orthodox church by the police. ${ }^{164}$

On the other hand, the material requisites of Kattı Geray's dreamed-of Seminary could not be realized either. The Scottish Missionary Society was in no position to undertake the enterprise financially and its appeals to the Russian government to that effect were not fruitful. ${ }^{165}$ Nonetheless, Kattı Geray did not give up the idea totally. He privately employed a Crimean Tatar teacher in Akmescit, to instruct Crimean Tatar children in the Christian faith, by using the Scriptures as textbooks. ${ }^{166} \mathrm{He}$ also distributed small sums of money to the poor, in order to tempt them to come to his lessons. ${ }^{167}$ All were of little effect. Even this "school" of Katt1 Geray did not live long: upon a letter of Prince Aleksandr Golitsyn to that effect, Katt1 Geray had to close down his "school" sometime by mid-1823. ${ }^{168}$

Kattı Geray's endeavors in the Crimea were not confined to a contemplated Christian educational institution for the Crimean Tatars, however. He would also visit the starving Tatar villages which had been struck by a very bad harvest to give the most needy there a small weekly allowance of flour and to propagate Christian religion. ${ }^{169}$ Kattı Geray, apparently, did attract attention from the part of the local Crimean Tatars in most places he visited, but this had to do with his being a "Sultan," rather than with the message he tried to convey. ${ }^{170}$ It must have been this attention which led him to propose the moving of the missionary station from Bahçesaray to Karasubazar, where he personally was received favorably. ${ }^{171}$ There is no doubt that nothing came out of all his efforts, since no evidence remains of their success.

As the work in the Crimea proved hopeless, the Scottish Missionary Society decided to suspend the station there and appointed Carruthers to a more promising

163. "Correspondence with missionaries in the Crimea. From Carruthers to the Directors of the Scottish Missionary Society, 4 February 1823," National Library of Scotland, Manuscripts, MS.8984: 49.

164. "Correspondence with missionaries in the Crimea. From Carruthers to the Directors of the Scottish Missionary Society, 21 March 1823," National Library of Scotland, Manuscripts, MS.8984: 49.

165. "Survey of missionary stations. Baktcheserai," art. cit.: 33.

166. Ibid.

167. R. Lyall, op. cit.: 239.

168. "Correspondence with missionaries in the Crimea. From the Sultan Katte-Ghery to the Directors of the Scottish Missionary Society, 27 June 1823," National Library of Scotland, Manuscripts, MS.8984: 51.

169. "Crimea," Scottish Missionary Register, vol. III, no. 7 (July 1822): 246; Report of the Scottish Missionary Society for 1823 (Edinburgh, 1823): 24-25.

170. “Crimea,” Scottish Missionary Register, vol. III, no. 7 (July 1822): 246.

171. "Correspondence with missionaries in the Crimea. From the Sultan Katte Ghery to the Directors of the Scottish Missionary Society, Sympheropole, 2 December 1822," National Library of Scotland, Manuscripts, MS.8984: 44. 
station in $1825 .{ }^{172}$ The departure of the missionary station, or rather that of the Carruthers couple was, in practice, the last nail in the coffin of Katt1 Geray's project of a Christian seminary for the Crimean Tatars.

\section{The end of the activities of the Scottish missionaries in the Russian Empire}

The death of Alexander I, who had been sympathetic to the Protestant missionaries and as well as to Kattı Geray himself, signalled a sharp turn in the work of the Scottish Missionary Society within the Russian Empire. The mystically minded Alexander was the ideal patron for the Scottish missionaries. No matter how little they could accomplish in converting Muslims or others, they could always count on the support, or at least the benevolence, of the Tsar. Kattı Geray's personal affinity with Alexander was also a critical factor. Now, this would change, just like the external and internal developments which could not help but affect the Russian government's consideration of the Scottish missionaries. Toleration of many influential figures of the Russian state and Church towards the activities of foreign and non-orthodox missionaries was diminishing even before the death of Alexander I. In 1824, in what the missionaries called the "Anti-Biblical Revolution in Russia," the Russian Bible Society, which had been founded with the cooperation of the Scottish missionaries and which had played an important auxiliary role in their activities, was practically paralyzed under pressure. Autonomous activities of the European missionaries, especially in the area of printing the Testaments and tracts were severely curbed and made subject to the state and Orthodox Church censorship. As for the Russian Bible Society, its already nominal existence came to an end when, on 12 April 1826, its activities were "temporarily" suspended by Nicholas I. 173

With or without these matters, the Scottish missions in the Tsar's domains, the one in Karas particularly, already had their own intrinsic sources of discomfort. The mission at Karas clearly entered a period of terminal crisis from $1821 \mathrm{on}$. In addition to the chronic problems of unstable circumstances and lack of success in proselytizing, the relations between the few missionaries themselves, as well as those between them and the directors of the Society back in Scotland, became very strained. It even reached the point of the Society's severing its ties with the elder of the colony, Alexander Paterson. In 1825, the latter petitioned the Russian authorities for abolishing the mission and turning all its properties and privileges to the German (Swiss) missionaries from Basle who had arrived in Karas in 1821. The local Russian authorities, including the famed (and dreaded) General Aleksei Ermolov, however, were not in favor of the continuation of the activities of foreign missionaries in the

172. Report of the Scottish Missionary Society for MDCCCXXV (Edinburgh, 1825): 18; T. Smith, J. O. Choules, A. M. Newport, op. cit.: 226.

173. W. Canton, op. cit.: 414-418; "Scottish Missionary Society," The Missionary Register for MDCCCXXV(1825): 393; W. Brown, op. cit.: 432. 
region, in the form of neither Scottish nor German ones. ${ }^{174}$ After more than a decade of bickering among the missionaries, in which the Russian authorities were also involved so far as it related to the official administrative matters of the village, the Scottish Missionary Society resolved to close its station at Karas in 1833. The closure of the station was officially approved by the Tsar Nicholas I in 1835.175

Karas might have had its own particular troubles, but there were shared problems in all the Scottish missions within the Russian Empire, rendering missionary work among its Muslim subjects thoroughly ineffective. In general, by mid-1820's even the Scottish Missionary Society was brought to admit the hopelessness of the overall situation. The Report of the Directors of the Society for 1822-1823 devoted a large space under the heading "Indifference and insensibility of the Tartars," deploring the discouraging news from all its stations. ${ }^{176}$ To quote the Society's own phrases, "the aspect of things in Russia had become so dark and gloomy, that many of the Directors had begun to entertain strong doubts, as to the propriety of persevering in cultivating a field which appeared so barren and unpromising." 177 By 1825, most of the Scottish missionaries in the Russian Empire were withdrawn back home. ${ }^{178}$ Together with the Crimean one, it was resolved to suspend the Scottish missionary stations in Orenburg and Astrakhan in 1825. The German United Brethren (Brüdergemeinde) and the London Missionary Society also shut down their stations, considering the present circumstances in Russia unfavorable. ${ }^{179}$ The last remaining Scottish missionaries in "Tartary" faced personal tragedies besides the lack of success in evangelizing: two of William Glen's children, one of John Mitchell's (both in Astrakhan), and one of Jacob Galloway's (in Karas), died of scarlet fever in 1826. ${ }^{180}$

One notable, if individual, exception to the gloomy picture for missionary work among the Muslims was the case of Muhammed Ali Kasim Beg, or Aleksandr Ivanovich Kazem-Bek. Incidentally, this case bore very interesting similarities to that of Kattı Geray Sultan-Kırım-Geray. Muhammed Ali's conversion took place at

174. "Vypiska iz dela o Shotlandskoi kolonii," Akty Sobrannye Kavkazkoiu Arkheograficheskoiu Kommissieiu, vol. VII (1878): 931-932.

175. For the details of the intermissionary dispute about the affairs of the Karas colony, see M. V. Jones, art. cit.: 66-76.

176. "Scottish Missionary Society. Discouragements...," art. cit.: 550-554.

177. "Scottish Missionary Society,” The Missionary Register for MDCCCXXV (1825): 391.

178. "Scottish Missionary Society. Anniversary," The Missionary Register for MDCCCXXV (1825): 384.

179. "Survey of missionary stations. Black and Caspian Seas," The Missionary Register for MDCCCXXV (1825): 45 and "Scottish Missionary Society," Ibid.: 393. The mission station in Astrakhan, in fact, continued to exist in the person of William Glen who kept working on the translation of the Old Testament to Persian and continued the usual, if vain, efforts of proselytizing among the local Muslims until 1833 when his engagement with the Scottish Missionary Society was terminated. "Black and Caspian Seas. Scottish Missionary Society," The Missionary Register for MDCCCXXX (1830): 359-360; Report of the Scottish Missionary Society for MDCCCXXXIII (Edinburgh, 1833): 9.

180. Report of the Scottish Missionary Society for MDCCCXXVI(Edinburgh, 1826): 21. 
a time when the spirits of the Scottish missionaries in the Russian Empire were lowest and provided them with a temporary revival of energy. ${ }^{181}$

Having descended from a Persian noble family, Muhammed Ali's father, Mirza Haji Kasim Beg had assumed prominent positions, including the post of the kadi of Derbend, before he settled in Astrakhan. Muhammed Ali was a young man fluent in Persian, Arabic and Turkish, and well-versed in Islamic studies. When he was teaching the missionaries Turkish and Arabic in Astrakhan, he gradually decided to convert to Christianity. In 1823, at the age of 21, he was baptized by the Scottish missionaries. While Muhammed Ali's conversion outraged his kinsmen, the missionaries were, of course, greatly elated. ${ }^{182}$ After all, he was one of the very few converts of the Scottish missionaries from among the Muslims of the Russian Empire, and, together with Kattı Geray, the most sensational one. Upon his baptism, to the deep regret of the missionaries, Kazem-Bek was compelled by the Russian authorities to break with the mission and enter the Russian state service. He subsequently became a professor at Kazan and St. Petersburg universities and an outstanding specialist on oriental languages and history. ${ }^{183}$ Aleksandr Ivanovich Kazem-Bek was included in the hereditary nobility of the Russian Empire. ${ }^{184}$

In spite of the excitement it gave to the missionaries, Kazem-Bek's conversion was a feat too late, too little for them. Just like the case of Kattı Geray, KazemBek's apostasy remained an exceptional and isolated case which did not couple with the conversion of any of his countrymen. Just like Kattı Geray, Kazem-Bek could not remain socially and culturally a Persian (or a Caucasian) and simultaneously a Christian. He would be totally detached from his former societal identity, and, together with his descendants, become part of Russian society in general, and of the Russian nobility in particular.

\section{The later part of Kattı Geray's life in the Crimea}

Crippled by the departure of the Scottish missionary organizations from the Russian Empire, Katt1 Geray was left alone in dealing with his grandiose projects of proselytizing among the Muslim peoples of the Russian Empire. As a matter of fact, he maintained his contact with the Scottish Missionary Society at least until early 1830s. Hoping for the coming of better times, he was agog for blocking, for a

181. "Scottish Missionary Society. Discouragements...," art. cit.: 552.

182. For detailed accounts of Muhammed Ali's conversion in contemporary missionary sources, see "Astrakhan. Scottish Missionary Society," The Missionary Register for MDCCCXXIV (1824): 486-489; Ross, "The Persian Convert," The Christian Keepsake and Missionary Annual (London, 1838): 155-168; W. Brown, op. cit.: 425-429.

183. For the life and activities of Aleksandr Ivanovich Kazem-Bek, see Magomed Abdullaevich Abdullaev, Kazem-Bek - uchenyi i myslitel' (Makhachkala, 1963); Agababa Kasumoglu Rzayev, Mukhammed Ali M. Kazem-Bek (Moscow, 1989).

184. V. V. Rummel, V. V. Golubtsov, Rodoslovnyi sbornik russkikh dvorianskikh familii, vol. I (St. Petersburg, 1886): 343-344. Aleksandr Ivanovich Kazem-Bek's descendants rose to prominence both within Russia and, after the 1917 Revolution, in emigration. 
prolonged and uncertain period, that small amount of individual contributions which had been donated to his project during his visits to Scotland and Ireland. The Scottish Missionary Society, however, thought differently. As this fund was collected from individuals for a special project and donated to the Society (i.e., not to Kattı Geray personally) and as there was not "the smallest probability" of resuming the missionary work of the Society in the Crimea, the Directors of the Society decided to return these contributions to their donors or to use them in other missionary enterprises of the Society with their approval. ${ }^{185}$ The very polite approach of the Scottish Missionary Society toward Kattı Geray notwithstanding, this clearly meant that he could cherish no prospect of practical support from the Society concerning the proselytising work in the Crimea for the future.

Apparently, in spite of all these disheartening setbacks, Kattı Geray still tried to propagate Christianity individually to his kinsmen in the Crimea. His task, already a very difficult one in the face of the staunch faith of the Crimean Tatars, was rendered even more hopeless given the lack of support on the part of the Russian Orthodox Church, which was anything but comfortable by the propaganda of a version of Christianity other than its own. So Kattı Geray's efforts in the Crimea to convert the Crimean Tatars to Christianity met with utter failure. He ended up not being able to make a single convert. ${ }^{186}$

Apart from unsuccessful missionary enterprises, Kattı Geray was also interested in the culture and history of the Crimea. As a matter of fact, his amateurish interest led to a spectacular archaeological discovery. In summer 1827, Katt1 Geray purchased four ancient stone plates from a local Crimean Tatar. One of them had a relief of a mounted warrior, while on the other three were inscriptions. Kattı Geray submitted these historical artefacts to I. P. Blaramberg, the director of the Odessa Museum of Antiquities, who was fascinated by them. The stones turned out to be relics of Scythian times. Upon this discovery by Kattı Geray, within a year Blaramberg launched archaeological excavations on the hill (Kermençik) above the city of Akmescit, which proved to be the location of the ancient town of Neapol (3rd century B.C.), one of the most important primeval settlements on the peninsula. ${ }^{187}$

Katt 1 Geray was able to lead a fairly comfortable life in the Crimea. Alexander I had bestowed upon him a pension of six thousand roubles which he would enjoy during the years to come. ${ }^{188}$ Evidently, Alexander I and Kattı Geray remained close

185. "Correspondence with missionaries in the Crimea. From William Brown to the Sultan Katte Ghery, Edinburgh, 27 January 1832," National Library of Scotland, Manuscripts, MS.8984: 82-84.

186. Edmund Spencer, Travels in Circassia, Krim Tartary, etc. vol. II (London, 1837): 89-90; A. Francis Steuart, Scottish influences in Russian history (Glasgow, 1913): 135.

187. Nikolai L'vovich Ernst, "Neapol' skifskii (k stoletiiu so vremeni pervykh raskopok)," Vtoraia konferentsiia arkheologov SSSR V Khersonese, 10-13 sentiabria 1927 goda (Sevastopol, 1927): 24; Tat'iana Nikolaevna Vysotskaia, Neapol' - stolitsa gosudarstva pozdnykh skifov (Kiev, 1979): 15; Vladimir Aleksandrovich Shirokov, Oleg Vladimirovich Shirokov, Simferopol'. Ulitsy rasskazyvaiut (Akmescit/Simferopol, 1983): 30; Viktor Khomenko, "Molchit Neapol' skifskii...," Golos Ukrainy(Kiev), 16 May 1998.

188. R. Lyall, op. cit.: 239; E. Spencer, op. cit.: 89. 
friends until the former's death in 1825. Whenever Alexander I visited the Crimea, they would meet and ride along the picturesque Crimean landscape. ${ }^{189}$ Following the death of Alexander I, his successor, Nicholas I, found the note of the former about bestowing a large amount on Katt 1 Geray. Nicholas proposed that Kattı Geray chose 1000 desiatins of land for a mansion anywhere in the Crimea instead of this money. Kattı Geray chose a mountainous place in the location called Demirci where he and Alexander I had taken a rest during the late tsar's last visit. ${ }^{190}$ Apart from the mansion in Demirci, Kattı Geray had a large dwelling in Akmescit, a beautiful seaside villa together with a vineyard on the right bank of the Souksu stream near Artek, and 15 desiatins of garden in Aluşta. ${ }^{191}$

In spite of his well-to-do life and known royal ancestry Kattı Geray had certain difficulties in certifying or confirming his noble status. That was why he applied to be included in the book of nobility (Rodoslovnaia kniga) in 1833.192 According to a family story, he had lost the documents concerning his origins by submitting the originals at an early date, possibly during his first visit to St. Petersburg. 193

Apparently, Kattı Geray's life was not much different from that of a typical local Russian nobleman-pomeshchik (landlord); he partly resided in Akmescit and partly preoccupied himself with agricultural matters in his estates. ${ }^{194}$ Kattı Geray SultanKırım-Geray died in Demirci in 1847. ${ }^{195}$ Her husband's death did not compel Anne Neilson Sultan-Kırım-Geray to return to her homeland and she continued to live in Akmescit. The outbreak of the Crimean War within a few years affected her life dramatically. That her home country and her adopted one were now at war with each other was an adequate source of distress. At least two of her sons fought against her own countrymen during the Crimean War. ${ }^{196}$ More troubles, however, were in store for her. She was residing in Akmescit, not far from the Crimean coast where the Allies landed. Soon after the allied landing at Kezlev (Yevpatoriia), General-Adjutant Aleksandr Sergeevich Menshikov, Commander-in-Chief of the Russian Armies in the Crimea, asked General-Lieutenant Vladimir Ivanovich Pestel', the civil governor of Tavrida, that Anne Neilson Sultan-Kırım-Geray be taken from Akmescit to Yekaterinoslav under surveillance. The reason for this measure was the interception of a letter from the British naval captain and the British governor of Kezlev

189. Reiswitz I: 28.

190. I. F. von Gersdorff, op. cit.: 7; Reiswitz I: 28-29.

191. TsGAARK, f. 49, op. 1, d. 5640,1. 18; I. F. von Gersdorff, op. cit.: 8; Subsequently, long after Kattı Geray Sultan-Kırım-Geray's death, his homestead in Akmescit became the hotel "Tavrida," one of the best hotels in the pre-revolutionary Crimea. Osman Magid, "Qırımnıñ Hanları Sülâlesiniñ Soñu," Yañı Dünya (Akmescit), 9 June 1995.

192. TsGAARK, f. 49 , op. 1, d. $5640,1.15$.

193. Ibid.: 7 .

194. Iurii Nikitich Bartenev, “Zhizn’ v Krymu,” Russkii Arkhiv (Moscow), no. 8 (1899): 555.

195. Reiswitz I: 29; Reiswitz II: 126.

196. J. B. P., art. cit. 
(Yevpatoriia) Saumarez Brock to her. ${ }^{197}$ In this letter, Captain Brock assured her that "in the case of the occupation of Simferopol by [the British] forces, all possible protection would be extended to her and her properties would be secure from arbitrariness and violence.” Brock also asked her whether she needed anything. ${ }^{198}$ Anne Neilson Sultan-Kırım-Geray, however, refused to go to Yekaterinoslav on the grounds of her poor health. ${ }^{199}$ When Tsar Nicholas I was informed of this, he stated that Anne Sultan-Kırım-Geray "was known to him as a very good woman" and ordered that in case of her sickness she might not be exiled but left in Akmescit under surveillance. ${ }^{200}$ Perhaps not being able to withstand all this distress, Anne Neilson Sultan-Kırım-Geray died in Akmescit not long after, in June 1855.201

\section{The children of Kattı Geray Sultan-Kırım-Geray}

Kattı Geray and Anne Neilson Sultan-Kırım-Geray had fourteen children, six of whom died during their early infancy. ${ }^{202}$ The first child of the Sultan-Kırım-Geray couple was Aleksandrina (Alexandrine) who was born in St. Petersburg in 1821. She was named after Alexander I and baptized by the Tsar himself at the Winter Palace. ${ }^{203}$ Among their other children, the names of the following are known: Alfred, Anna Margarita (Anne Margaret) (b. 1824), Aleksandr Canıbek Geray (b. 1826), Charlotte Leonis Alime (b. 1828), Jana (?), Andrei Arslan Geray (b. 1832), Nikolai Alfred Adil Geray (b. 1836), Valerian, Victoria, Isabella, Maria, and Gloria. ${ }^{204}$ All the children of Katt1 Geray were baptised as Protestant Christians. ${ }^{205}$ As can be seen from the names of his children however, despite his firm commitment to Christianity, Kattı Geray officially gave some (if not all) of his children traditional Crimean Tatar (or Turkic/ Muslim) names next to their Christian and European/Russian names. This indicates

197. "From General-Adjutant Aleksandr Menshikov to General-Lieutenant Vladimir Pestel', 30 September 1854," TsGAARK, f. 26, op. 1, d. 20010,1. 1, and "From the Head [Nachal'nik] of the Tavrida Guberniia to Colonel Bunin, 6 October 1854," TsGAARK, f. 26, op. 1, d. 20010, 1. 10. For Captain Saumarez Brock and his assignment in Kezlev (Yevpatoriia), see Russian war, 1855. Black Sea. Official correspondence (London, 1945): 426-435.

198. "The copy of the letter from Saumarez Brock to Anne Neilson Sultan-Kırım-Geray, 24 September 1854," TsGAARK, f. 26, op. 1, d. 20010,1. 56.

199. "From the widow of Sultan Kattı Geray Kırım Geray to the Police Chief of Simferopol, 3 September 1854," TsGAARK, f. 26, op. 1, d. 20010,1. 7.

200. TsGAARK, f. 26, op. 1, d. 20010,1. 23.

201. J. B. P., art. cit.; Reiswitz II: 126.

202. Reiswitz I: 28; Reiswitz III: 9.

203. "Copy of Prince Aleksandr Golitsyn's letter to Kattı Geray dated 28 August 1812 [1821]," TsGAARK, f. 49, op. 1, d. 5640, 1. 54; I. F. von Gersdorff, op. cit.: 7; Dmitry Fedosov, The Caledonian connection. Scotland-Russia ties - Middle Ages to early twentieth century (Aberdeen, 1996): 61.

204. I. F. von Gersdorff, op. cit.: 8; TsGAARK, f. 49, op. 1, d. 5640, 1. 15, 59-61; Reiswitz I: 29; N. I. Afanas'ev, Sovremenniki, vol. II (St. Petersburg, 1910): 404.

205. "Protocol of correspondence," TsGAARK, f. 49, op. 1, d. 5640, 1.58; Charles [Karl Heinrich Emil] Koch, The Crimea and Odessa (London, 1855): 53. 
that he was not totally severed from his roots and wished to preserve at least a part of his Crimean Tatar identity and culture.

Kattı Geray's surviving children had interesting life stories and they and their offshoots were scattered throughout the whole of Europe, if not beyond. Katt1 and Anne's daughter, Aleksandrina (Alexandrine) became a lady-in-waiting to the wife of the Grand Duke Constantine and later married the German Baron von Gersdorff. She was also connected to the Danish court and a friend of the British Queen Alexandra. ${ }^{206}$ Charlotte Alime married Baron von Gersdorff, upon the death of the latter's wife, her sister. The couple had ten children. Charlotte Alime died in Schlesswig in 1909 and her descendants lived in Germany. ${ }^{207}$ Anne Margaret married a Briton named Thomas Upton and settled in Edinburgh. ${ }^{208}$ Canıbek and Andrei participated in the Crimean War. Both, as well as Jana (?), died quite young. ${ }^{209}$

\section{Nikolai Aleksandrovich Sultan-Kırım-Geray}

Among the children of Kattı Geray, Nikolai Aleksandrovich Adil Geray SultanKırım-Geray had the most distinguished career in Russia and the Crimea. Nikolai Aleksandrovich had studied in the Pavlovskii cadet corps and completed his education in the Nikolaevskii Academy of the General Staff. He entered military service in the Life Guard (Leib-gvardiia) Lithuanian Regiment in 1856 and retired from the army with the rank of first lieutenant three years later. ${ }^{210}$ In 1863 , he was transferred to the civil service. First, he served in the law courts in Kefe (Feodosiia), in the Crimea. In 1870, he was elected mayor (gorodskii golova) of the same town. Within four years, he rose to become chairman of the zemstvo administration and the marshal of nobility of the uyezd of Kefe (Feodosiia). His subsequent posts included the directorship of first the Yekaterinoslav, and then the Tavrida revenue departments (kazennaya palata), and membership of the Caucasian Council of the Ministry of Finance and Transcaucasian Statistical Committee. In 1905, he became the deputy to the governor (namestnik) of the Caucasus. Next year, he was appointed a member of the Senate. ${ }^{211}$ Before the beginning of the First World War he was designated Privy Councillor (tainyi sovetnik) to the Tsar. ${ }^{212}$

206. J. B. P., art. cit.

207. Reiswitz III: 9.

208. J. B. P., art. cit.

209. Canıbek Geray and Jana (?) were very much liked by the Crimean Tatars who said of them "You belong to us" and upon their death it was believed that their corpses were stolen by the Crimean Tatars who buried them according to Muslim rituals. I. F. von Gersdorff, op cit.: 10-11. 210. TsGAARK, f. 26, op. 1, d. 23360; N. I. Afanas'ev, op. cit.: 404-405. There are minor errors in Afanas'ev's biography of Nikolai A. Sultan-Kırım-Geray, as he gives Sultan-KırımGeray's military service as five years and his last rank as podporuchik, which is refuted by the latter's official military records.

211. N. I. Afanas'ev, op. cit.: 405. Nikolai A. Sultan-Kırım-Geray was married to the Countess I. I. Gendrikova.

212. Ia. I. Kefeli, "Drevniaia krymskaia byl' (Mudrets khakim Isak)," Vozrozhdenie (Paris), no. 47 (November 1955): 58. 


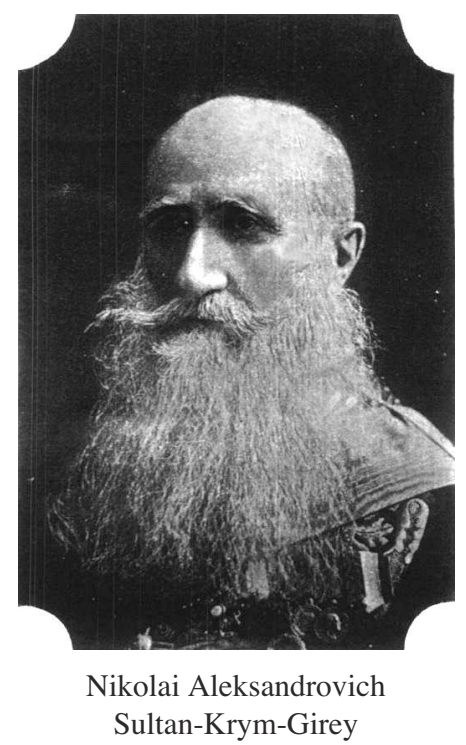

Nikolai A. Sultan-Kırım-Geray was known to be a democratically and progressively-minded administrator. ${ }^{213}$ While he served as the deputy governor in the Caucasus, he would stand out with his liberal and conciliatory approach in the midst of the bloody revolutionary turmoil there in 1905.214 These aspects of his personality were evident during his life and service in the Crimea too. At times, he appeared to be a quite outspoken defender of the rights of the Crimean Tatars in agrarian and land matters. During a discussion about the landless Crimean Tatars in the Tavrida provincial assembly (gubernskoe sobranie), he recounted that the Tatars were still in a depressed situation and the landless ones were being forced out of places of residence and did not know where to go. Resenting the absence of a single Crimean Tatar among the members of the then-defunct commission for restructuring the lives of the Crimean Tatars, Sultan-Kırım-Geray pointed out the oddity of the membership of Ivan Konstantinovich Ayvazovskii, whose personality and artistic talents everybody respected, but who was not particularly known for his familiarity with the lives of the Crimean Tatars. ${ }^{215}$ Such demarches on the part of N. A. Sultan-Kırım-Geray must have won him the sympathy of the Crimean Tatars. İsmail Bey Gaspıralı, the renowned Crimean Tatar publicist and the mentor of the national awakening and reform movement among the Turks of the Russian Empire, appreciated him too. Gaspıralı's newspaper Tercüman would often carry information and favorable

213. V. A. Shirokov, O. Shirokov, op. cit.: 120.

214. Ronald Grigor Suny, The making of the Georgian nation(London, 1989): 167 and 170.

215. V. Kh. Kondaraki, "Russkoe gospodstvo v Krymu," in V pamiat' stoletiia Kryma. Istoriia i arkheologiia Tavridy (Moscow, 1883) : 99-100; M. Goldenberg, "Krym i krymskie tatary," Vestnik Evropy (St. Petersburg), vol. 104, no. 6 (1883): 81-82. 
comments about his promotions. ${ }^{216}$ Gaspiralı supported the proposal that SultanKırım-Geray be appointed to the post of the governor of the Caucasus, in event of the incumbent one, Illarion Ivanovich Vorontsov-Dashkov, being dismissed. ${ }^{217}$

Besides his military and civil career, Nikolai A. Sultan-Kırım-Geray was very much interested in the history, archaeology, and ethnography of the Crimea. He was one of the founders of the prestigious Tavrida Scholarly Archival Commission in 1887. ${ }^{218} \mathrm{He}$ gave several scholarly speeches there, ${ }^{219}$ and donated a large number of valuable books to the library of the commission.220 He was also known for his donation of a wooden bridge to the city of Akmescit. ${ }^{221}$ As a man of highly respected scholarly and public stature, Nikolai A. Sultan-Kırım-Geray left an enduring reputation in the Crimea. Accordingly, in November 1902, the Akmescit (Simferopol) city duma (municipal council) resolved to name after him a large street ("Sultanskii") which was built on the territory donated by N. A. SultanKırım-Geray to the city.222 A boulevard in Akmescit was also named "KrymGirey" (Kırım Geray). ${ }^{223}$ N. A. Sultan-Kırım-Geray barely survived the initial period of the Russian revolution and was reported to have died of hunger during the years of "War Communism" in Petrograd, in 1921.224

216. "Ahbâr-1 Dahiliyye (Kırım)," Tercüman (Bahçesaray) (17 December 1895); "Sultan Kırım Geray," Ibid. (22 March 1906). The mere fact that Nikolai A. Sultan-Kırım-Geray happened to be a descendent of the Crimean khans, albeit a Christian one, caused the resentment of some Armenian circles upon his appointment as the deputy of the governor of Caucasus. "Hilâl Koteriliyor," Ibid. (13 March 1906).

217. “Sultan Kırım Geray,” Tercüman(13 January 1906).

218. Sergei Borisovich Filimonov, Khraniteli istoricheskoi pamiati Kryma (Akmescit/ Simferopol, 1996): 12.

219. His scholarly speeches in the Tavrida Scholarly Archival Commission included, "On the desirability of studying the family archives of A. I. Kaznacheev, the former Governor of Tavrida and the head of the provincial nobility, by the members of the Tavrida Scholarly Archival Commission" (28 December 1889), "On the condition of the monument of Emperor Alexander I located on the pass on the road from Simferopol to Aluşta" (23 January 1892), "The memories of G. K. Kireenko, V. V. Oliv, and A. N. Truvorov" (11 April 1896). S. B. Filimonov, op. cit.: 87.

220. "Spisok lits, pozhertvovavshikh knigi v biblioteku Tavricheskoi uchenoi arkhivnoi komissii," Tavrika (Akmescit/Simferopol, 1998): 25. Apparently, he had in his possession, a number of rare materials pertaining to the Crimean Tatar culture and ethnography. Andrei Nepomniashchii, "Izuchenie krymsko-tatarskogo naroda v otechestvennoi orientalistike v nachale XX veka," Gasırlar Avazı / Ekho vekov (Kazan), nos. $3 / 4$ (28/29) (2002): 238.

221 . In the early twentieth century, this bridge was replaced by a new one which was known as "Arkhivnyi." V. A. Shirokov, O. Shirokov, op. cit.: 120.

222. Not surprisingly, the name of the street did not survive the Soviet times. Initially, the street was named after Maksim Gorkii. It was renamed, however, in 1936 after Fanni Borisovna Shpolianskaia, a Bolshevik underground activist who died at the hands of the Whites in the Crimea in 1920. V. A. Shirokov, O. Shirokov, op. cit.: 162.

223. Krym-Girey Boulevard was renamed "Noiabrskii" in 1924, and "Ivan Franko" in 1960. Vladimir Evgen’evich Poliakov, Simferopol'. Spravochnik po ulitsam (Akmescit/Simferopol, 1996): 143.

224. Roşen Cafaroviç Seyfulla, Zapiski potomka khana Krym-Gireia (Moscow, 2000): 13; Ia. I . Kefeli, art. cit.: 59. N. A. Sultan-Kırım-Geray had a daughter, about whose fate we do not possess any information. 
It seems that the surname Sultan-Kırım-Geray as such has not survived to our day. The descendants of Katt1 Geray, however, have been scattered in Russia, Germany, Britain, the United States, and possibly a number other countries. It was estimated that (during the late 1970's) there were some fifty people descending from Kattı Geray Sultan-Kırım-Geray.225

\section{Two other cases of baptised Gerays}

We have been able to find at least two other cases of baptism of members of the Geray dynasty following the Russian invasion of the Crimea, with the possibility of a direct or indirect relationship to Kattı Geray. One of them concerns the baptism of the probable grandfather of Akim Pavlovich Shan-Girey. Akim Pavlovich ShanGirey (1818-1883) was known to the public as a close friend and relative of the famed Russian poet Mikhail Iur'evich Lermontov, who published one of the most important memoirs about the life and work of this great figure of Russian literature.

As his surname indicated, Akim Pavlovich Shan-Girey descended from the Geray dynasty and, as it had been claimed, from the line of the last khan, Şahin Geray Khan. According to the story related by his daughter, Evgeniia Akimovna, in the wake of the establishment of Russian rule in the Crimea, sometime in 1783 or 1784 , a twenty-year old Geray had been taken prisoner and presented as a "gift" to the Empress Catherine II. The latter had kept him in his court (where he must have been converted to Christianity) and had him married to one of her ladies of honor. From him descended the Russian line of baptised Gerays, to which Akim Pavlovich Shan-Girey belonged. As betokened by Akim's patronymics, his father was named Pavel and his grandfather was Petr (obviously his Christian name). Evgeniia Akimovna's family story had it that the Geray who had been taken to Catherine's court had two brothers. His elder brother had fled to Persia and had hidden in a ravine. The younger brother, however, disappeared from sight for a couple of years before he showed up in England, where he married and started the "English" branch of Gerays. 226

The story of the younger brother bears unmistakable similarities to the case of Kattı Geray. Since the presence of no Geray other than Kattı Geray in Britain in those years is known, it is quite possible that Kattı Geray's case was directly linked to that of Akim Shan-Girey's grandfather. However, the account of Evgeniia Akimovna needs to be accepted with a degree of reservation, as it clearly contains some incongruities due to her lack of familiarity with events that had taken place such a long time ago. Unlike Kattı Geray, neither Pavel nor Akim Shan-Girey (who were, of course, Orthodox Christians) were known to display any interest in, let alone work among the Crimean Tatars. Incidentally, Akim Shan-Girey was born in

225. Reiswitz I: 29.

226. V. A. Manuilov, S. I. Nedumov, "Drug Lermontova Akim Pavlovich Shan-Girei," Mikhail Iur'evich Lermontov. Sbornik statei i materialov (Stavropol, 1960): 252. 
the mansion of his mother's side (whence he was related to Lermontov) in the North Caucasus, not far from Karas, in 1818.227

The other case of Christianized Gerays (after the Russian invasion of the Crimea) involves the descendants of a certain Selim Geray. Our entire information about this line is based on an article about the life story of the engineer Vasilii Dmitrievich Selim-Girey which appeared in Izvestiia (Moscow) in 1966. According to the meager information provided by the article, Vasilii Dmitrievich was born in Eskikırım (Staryi Krym) in 1879 as the son of Prince Dmitrii Vasil'evich SimovKhan Selim-Girey, a captain of the first rank, and Tat 'iana Andreevna (née Koprova) of noble birth. Both parents were of the Greek Orthodox faith. As Prince Dmitrii Vasil'evich served as the naval attaché of the Russian Empire in London, young Vasilii spent several years in England, where he studied at Norfolk College. The places of his education would follow his father's assignments abroad, i.e., Berlin, Bern, and Zurich. He became an engineer, and as such, he participated in the First World War. Certainly, he lost all his properties following the Bolshevik revolution. Still, he somehow survived communist times and worked as an engineer under Soviet rule, though not without a period of persecution and imprisonment during the Stalinist years. No interest on the part of Vasilii Dmitrievich Selim-Girey towards his background is known, except for an instance when he allegedly ran away from the Crimean Tatars who approached him after learning his ancestry during a vacation in the Crimea. ${ }^{228}$ Although the fact that he was born in the Crimea might suggest a possible link with the line of Kattı Geray, his family's Orthodox faith and the surname "Selim Girey" renders this unlikely. It is not clear whether his father was permanently resident in the Crimea or simply happened to be there at the time of his birth. In any case, this line did not seem to stand out as Gerays during the nineteenth century or later, and the reliability of the information in the above-mentioned article has been subject to dispute since then. ${ }^{229}$

\section{Conclusion}

Following the demise of the Crimean Khanate, the descendants of the Geray dynasty were scattered mostly in the domains of the Ottoman Empire (in areas

227. Ibid. A portrait of Akim Pavlovich Shan-Girei bears witness to his unmistakable Crimean Tatar features. Ibid:: 253.

228. I. Buzylev, “Odisseia inzhenera Gireia,” Izvestiia (Moscow) (28 February 1966).

229. Buzylev's article was reprinted in the Crimean Tatar press in 1994: I. Buzylev, "Odisseia inzhenera Gireia," Qırım (Akmescit) (15 October 1994). This reprint of the article, which had originally been published during times when the Crimean Tatars had officially been a "nonpeople" in the Soviet Union, was not welcome to everybody. An indignant reply was soon published, where Buzylev was accused of discrediting the Crimean Tatars, falsifying their culture, and linking them with a man who served first the Father Tsar, then the Provisional Government, and finally comrade Bolsheviks, and who was a Russian and Christian, and thus nothing to do with the Crimean Tatars save for the Turkic origin of his surname. N. Biyazova, "Cherez 28 let posle 'Odissei...' (po sledam odnoi publikatsii)," Ibid. (5 November 1994). 
which are parts of contemporary Turkey, Bulgaria, Macedonia, Greece, etc.) and, to a lesser extent, in the Northern Caucasus. Proud of their origins, many of them lived the lives of local notables, relatively undisturbed by their past. All of them remained Muslims in basically Muslim environments. The example of Kattı Geray and his descendants remained an isolated and atypical one; no other member of the Geray dynasty (with the possible exception of the Shan-Gireys) is known to follow suit. Anyway, with the exception of rare individual cases, there were no incidents of conversion to Christianity among the Crimean Tatars. True, during the late and post-Golden Horde period, there had been plenty of cases of Tatars from the Crimea (and the other parts of the Golden Horde) who, having settled in the Muscovite domains for one reason or another and having entered Russian service, had ended up embracing Christianity, usually with the acquisition of noble status. Many a Russian family of prominence descended from such progenitors. Clearly, as a rule, in all such cases Christianization meant total Russification, and it was unthinkable for these apostates to continue to live in Tatar society. This was a legal impossibility during khanate times for obvious reasons, and was the case socially under Russian rule. Kattı Geray's case constitutes a characteristic example, as he lived, geographically speaking, among the Crimean Tatars, but no longer as one of them.

Despite the fact that Kattı Geray (at least he spoke Crimean Tatar as his mother tongue) and some of his descendants showed a certain degree of interest in the affairs of the Crimean Tatars, apparently neither they themselves nor the Crimean Tatar community considered them as Crimean Tatars any more; they were Russian dvoriane of Crimean Tatar background, pure and simple. Their background going back to the Crimean Khanate was of course known by everybody (after all, their surname was "Sultan-Krym-Girey") and it was these roots which justified their status as members of the nobility. As such, at least the Crimean Tatar notables displayed a certain respect towards them. But that was all. Clearly, they were no longer part of Crimean Tatar society; neither the Crimean Tatars considered them as such, nor did they display any wish to be recognized as such. As was the case with Nikolai Aleksandrovich Sultan-Krym-Girey, their interest in Crimean history and culture in general was apparently considered in no different way than those of many learned and cultured Russians and other Europeans. Their belonging to a different version of Christianity than the Russians obviously did not matter at all to contemporary Crimean Tatar society which was not very much interested in such niceties as sectarian distinctions among the infidels. There had never been such a thing as a Christian Tatar; when a Tatar became a Christian, as so many had done previously in history, he would become a Russian. As was the case in many a similar society, among the Crimean Tatars or other Muslims in the Russian Empire, Islam proved much more then a personal belief but the most important element of societal identity. The case of Aleksandr Ivanovich Kazem-Bek was essentially the same in a parallel context.

It should be noted that the second half of the nineteenth century (and especially its last decades) was known as the period of the emergence of an enlightenment and national awakening movement among the Crimean Tatars, as well as for many 
other Turkic and/or Muslim subjects of the Russian Empire. This being the case, such people as the descendants of Kattı Geray (or Kazem-Bek, for that matter), even when they became esteemed scholars or intellectuals of some sort dealing with the "eastern peoples," never in any fashion get involved in such enlightenment movements.

The case of Kattı Geray and his children might bear some similarities to, but was basically different from, those certain individual Turkic and/or Muslim intellectuals of the first part of the nineteenth century. Among such individuals one can count the names of the Kazak Çoqan Valihanov, the Azerbaijani Turkish Abbaskulu Han Bakıhanlı, the Crimean Tatar-cum-Adyges Han Geray, Sultan Kırım Geray, Sultan Gazi Geray, the Adyge Shora Bekmurze Noghumuka (Nogmov), etc. These individuals belonged to local native noble families and, having acquired Russian (mostly military) education, served for some time in the Russian army or bureaucracy. They were Russianized in most respects and had no problem of admission to Russian society. Yet they did not totally break off from their native peoples nor were they rejected by them (not least, due to their respected origins). None of them renounced Islam, formally or otherwise. They were interested in, and concerned in a certain way, with their indigenous peoples. They would conduct researches and prepare scholarly or semi-scholarly treatises about their peoples. In that respect, such individuals left a significant amount of ethnographic, historical, literary, sociological, and geographical material of a very interesting and unique nature concerning various eastern peoples of the Russian Empire. They were not against Russian rule in their native lands (though they might occasionally speak out against this or that aspect of misrule) and would actually consider Russian culture and science as vital for the progress of their backward peoples. As such, they were certainly favored by Russian circles not only as the paradigm of good natives or "civilized savages," but also as useful personal bridges to the native societies in these troubled lands. Hardly any of these individual intellectuals became initiators of an authentic native enlightenment movement among their peoples, though they would subsequently be remembered for their unique roles and works. The generation of native enlighteners would emerge in these societies several decades later from among personalities with certain connections with Russian culture but obviously with a much firmer standing and ties with their respective traditional societies.

Kattı Geray and his descendants could not be included even in this category of individuals of the "pre-enlightenment" period of the Turkic and/or Muslim peoples of the Russian Empire, as the latter retained at least the formal appearance of their traditional ethnic/religious identity. At a time when there was nothing resembling a Crimean Tatar intellectual or educated stratum (in the modern sense), Kattı Geray and his sons, with their relatively more educated background and positive credentials with the Russian government could have played a role. This did not take place, if not for anything else, due to their alienation from the society of their ancestors. Still, Kattı Geray and his sons remained the only Gerays of the male line to live in Russian-ruled Crimea throughout the nineteenth century. They were 
hardly considered as of their own by other members of the Geray family (or by most other Muslims) due to their unacceptable apostasy, but, ironically, this was the very reason for their being allowed to live in the land of their ancestors.

Today there are thousands of descendants of Gerays, many of whom even retain the name as their surnames, living predominantly in Turkey. Although more than a few of them are aware and conscious of their background, they have no organic or social connections between them except among immediate relations. Today hardly anyone among them stands out claiming the historical fame of the dynasty, let alone with any political implications for contemporary Crimean Tatars. Thus, as even the core Muslim line of the Geray dynasty is about to disappear save for vague ancestral memories, their exceptional Christianized branch or branches have long become forgotten.

Bilkent University

Department of International Relations

Bilkent 06800

Ankara

Turkey

kirimli@bilkent.edu.tr 